\title{
PRIMARY WRITTEN RECORDS AS A SOURCE FOR CULTURAL CHANGE WITHIN THE LATE ROMAN CITIES OF THE CENTRAL BALKANS
}

\begin{abstract}
This article revisits an old phenomenon in the Macedonian and general Balkan scholarship on late antiquity: the end of gladiator games and other spectacles, and especially, the alleged connection with the emergence of Christianity and imperial bans. In international scholarship, such notions have been considered outdated for a considerable length of time. However, these ideas are still rampant in local scholarship and used to interpret evidence from even most recent excavations (2010-2020s). Therefore, this author felt the need to revisit the issue, framed within a dataset that allows to juxtapose local archaeological evidence both with primary written sources and the broader international scholarship in order to finally lay to rest the connection between imperial promulgations and the abandonment of both spectacles and spectacle buildings.
\end{abstract}

Key words. - Late Roman law, spectacle buildings, gladiator fights, spectacles, abandonment, Christian, pagan, secular, sacred.

\section{Introduction: background and methodology}

This article is a follow-up of my previously published work on the use of primary written sources in the local scholarly tradition and the consequences for the interpretation of various aspects of late antique urban culture. ${ }^{1}$ The scholarship in question has been and is still dominated by theories created decades ago by an over-reliance on primary written sources and the imaginative interpretation of archaeological evidence to support them. The goals of this article are therefore two-fold. Firstly, it aims to raise awareness among the international scholarly community about older, inherited issues in the discourse about late antiquity coming from North Macedonia, by reiterating and expanding on the conlusions in my previous work. ${ }^{2}$ Secondly, it addresses the current generation of late antique scholars in the country to adopt a more critical

\footnotetext{
${ }^{1}$ Jarić 2017: 387-414.

${ }^{2}$ Ibid.
} 
mindset when it comes to distinguishing between data and interpretation.

These older theories are indeed pervasive in the research of several generations of archaeologists, though it goes without saying that such issues were not limited to the Balkans. ${ }^{3}$ However, there are several factors that created a unique situation in which these theories thrived long after similar notions were abandoned in international scholarship. Firstly, excavations, preservation, and presentation of more luxurious buildings such as Early Christian basilicas and urban residences dominate the local research agenda, as the remains of these buildings attract funding for both research and tourist visits. Late antique settlements, usually of humbler dimensions and building materials, though crucial for understanding the development of late antique settlement organisation, are not given enough attention during excavations, conservation, and publication, as they are usually seen as the inglorious end of previously thriving cities. Secondly, there is little engagement between local and international discourse on late antique urbanisation. Macedonian archaeologists, with few exceptions, publish mainly in their native language and in local journals. Often, these works are physically unavailable to international scholars since, apart from sharing on platforms like academia.edu, they are rarely digitally accessible, and Macedonian is a language which few people outside the Balkans actively use. The same obstacles work the other way, too. In North Macedonia, archaeology is still a profession without a private sector; therefore, archaeologists are still dependent on the access to international scholarship provided by public museums, faculties, and research centres, which is practically non-existent. ${ }^{4}$

Thirdly, the development of intellectual thought in a country without commercial archaeology and private think-tanks is monopolised by academic faculties. Currently, there are only two departments that offer education in archaeology at the universities of North Macedonia: the Faculty of Philosophy in Skopje and the Faculty of Education in Stip; the latter was founded in $2007 .^{5}$ The Department in Skopje has a

${ }^{3}$ On the field of late antiquity and the ideological, methodological, and practical issues of its development and the regional variations thereof: Ando 2007: 59-76, Rebenich 2007: 77-92, and Brandt 2007: 156-169.

${ }^{4}$ There are no foreign-run schools or projects which facilitate engagement between local and international scholars, with two notable exceptions - the Konjuh and Kostoperska Karpa Projects. See Donev et al, 2017: 73-90 for Kostoperska Karpa and https:// www.konjuh.mk/\#pocetna for history of research and available publications on Konjuh (last consulted on July $9^{\text {th }}, 2021$ ).

${ }^{5}$ Department in Skopje: the newly-founded Faculty of Philosophy offered courses in Byzantine studies, art history and archaeology of Macedonia taught by Nikolai Okunjev. These courses were taught by Balkan scholars who also excavated at Stobi and Scupi and founded the Journal of the Scholarly Society of Skopje. The department and the journal closed with the advent of World War II. Development of archaeology and art history in pre- and post-war Macedonia: Makuljević 2012: 461-72. 
much longer tradition; its beginnings can be traced to 1920, when the first Faculty of Philosophy was founded as an autonomous branch of the Faculty of Philosophy in Belgrade. The department functioned continuously until 1941, and although there were several attempts to revive it in the late 1940s, it would not be fully reopened until the academic year 1973/1974.

The Department in Skopje was and still is the main carrier of the scholarly torch in the fields of art history and archaeology. The sporadic interruptions in its functioning certainly took their toll. The same is true for the interruption of the cooperation between the department and similar departments at ex-Yugoslav faculties during the social and military turmoil that was the disintegration of Yugoslavia in the early 1990s, and the armed conflicts in North Macedonia, Serbia, and Kosovo during the 2000s. ${ }^{6}$

The last factor, but not the least, is human nature. There is a tendency not to challenge older theories because that equates to challenging the person who created them. The academic communities in the Balkan countries are small and self-constricted. This means that the development of a field, both the research and the educational part, is dictated by one or two persons holding important professorships and whose opinions are held as the utmost authority. This reflects also on prospects for employment for young professionals and scholars, especially in archaeology as the only career options are teaching at a public university or working in a public museum. Therefore, if one of these figures of academic authority propagates a theory which happens to misinterpret or misunderstand a written source or archaeological evidence, there will be a score of younger generations of researchers who will repeat the same notions in their work, either because their training is insufficient to notice the discrepancy or because to voice a contradictory opinion would be career suicide. ${ }^{7}$

Such is the academic milieu in which most of the local secondary literature used in this article was created. The discussion here will be led through examining primary written sources and what they can tell us about the cultural changes within the late Roman cities of the central Balkans. A phenomenon evident both in written sources and material culture will act as focal point of discussion: the the abandonment of spectacle buildings as an example of the religious, social, and economic changes in cityscapes. Much ink has been spilt in local scholarship on this topic, and therefore its sheer prevalence in a copious amount of literature, demands addressing in this article. Furthermore, this topics lends itself well to another important methodological question, that is the importance of defining the limits of any narrative: how much does the material and text allow us to say, and where does our interpretation start?

\footnotetext{
${ }^{6}$ Kaiser 1995: 99-11, Makuljević 2012: 461-72.

${ }^{7}$ On similar issues pertaining to modern Macedonian historiography: Brunnbauer 2003-4:161-82.
} 


\section{The use of primary written sources and their application in interpreting archaeological evidence in local and regional scholarship}

There is an almost century-long tradition in local scholarship to attribute the end of spectacle games and theatrical performances to an imperial ban. The original excavators of the spectacle buildings in the Roman cities of modern-day North Macedonia noticed that the practice of frequenting and maintaining theatres started to decline from the fourth century onwards. They explained this abandonment of spectacle buildings by imperial promulgations banning such activities. Late Roman laws are indeed the predominant contemporary written source that deals with these problems. However, these changes observable in other cities of the central Balkans and elsewhere in the empire are too complex and multi-faceted to be ascribed to imperial promulgation. Therefore, in this section of the article I examine the creation and proliferation of the theory that ascribes theatre abandonment to imperial laws and why it is still pervasive in local scholarship. I shall also broaden the discussion by introducing an overview of the relationship between maintenance of spectacle buildings and spectacles themselves, as well as the religious dimensions of games and spectacles and how pressure on pagan traditions and the transformation of the institutions in charge for giving shows. I include a dossier of archaeological evidence on spectacle buildings throughout the Roman empire, in an attempt to contextualise the textual discussion.

In his deliberation on the archaeological record and the problems of its interpretation in the discourse of late antique archaeology from its nascence to present day, Olof Brandt writes:

The chief point is, however, that only a specialist can master his evidence and his method well enough to use it to write history; only trained archaeologists can fully understand, interpret, and explain evidence from an excavation. It is in that sense that archaeologists have to see themselves as historians. Of course, it is challenging to relate archaeological evidence to text. Textual historians do not always appreciate all the nuances of archaeological evidence; but it has to be said that many archaeologists treat texts with comparable superficiality. This problem will probably not be resolved in the near future, not least because knowledge of classical language is becoming the privilege of fewer and fewer specialists. ${ }^{8}$

Brandt summarises succinctly the issues which late antique archaeologists face: poor treatment of written sources and archaeological record alike, lack of discussions between scholars of different training working in the same field, and the dying art of working with written sources in their original language. ${ }^{9}$ When it comes to the local late anti-

\footnotetext{
${ }^{8}$ Brandt 2007: 159.

${ }^{9}$ Less than a month before this article was written, the University of Princeton ended the requirement for their Classics majors to learn Greek or Latin: https://paw.prince-
} 
que scholarship of North Macedonia, these issues discussed by Brandt are further exacerbated by the factors I outlined in the introduction above. While working with the local secondary literature, I have identified two main ways in which a primary written source is misread: it is either misunderstood, or misinterpreted. Misunderstanding of sources happens when the author using them does not comprehend fully the information conveyed; either because he/she has no working knowledge of the ancient language in which the source is written or is using a translation which is in some respects inaccurate, or he/she is referring to the source via a proxy, that is, citing it from secondary literature.

Misinterpretation of a written source is expressed in applying information from a known source more broadly and then using the conjecture as a solid fact, even though it is not mentioned in the source themselves. The misunderstanding of sources seems more innocent, a mistake arising from overconfidence in one's abilities or a superficial approach to research. Misinterpreting can be taken as a modus operandi. When a researcher is trained to look for an explanation in primary written sources and finds none, it is very easy to be tempted into a broader interpretation that will offer an answer. I have discussed the academic hierarchy in the Balkans and how a theory created by one of the academic authorities is perpetuated. In this manner, local scholarship is locked in an outdated state, where new material is form-fitted to support older theories. The consequence of not challenging older ideas and authorities is to nullify the outcome of systematic excavations which could have rewritten the history of the ancient city, if treated and published properly.

\subsection{The theory of theatre abandonment as a result of imperial laws}

In my opinion, the theory of the abandonment of spectacle buildings due to an imperial ban is a prime example of a primary written source being misunderstood. This theory arose in regional scholarship between the two world wars, when a team from the Museum of Serbia excavated Stobi. The excavations were supervised by Balduin Saria, who published a report on the theatre in Stobi and whose abandonment he attributed to a law of Constantine issued in $325 .{ }^{10}$

ton.edu/article/curriculum-changed-add-flexibility-race-and-identity-track (last consulted on July $\left.9^{\text {th }}, 2021\right)$.

${ }^{10}$ Saria 1937: 12. Non vidi, thus I cannot tell whether a primary source was cited. The reference is cited in this form by almost all authors I will discuss further. Saria was also one of the many lecturers at the Seminar of art history and archaeology in Skopje during the 1920s, as was Nikola Vulić. Vulić joined Saria at the excavations in Stobi, but his primary project was the excavation of the Roman theatre at Scupi. His theories regarding the theatre are still held in regard; Vulić 1961: 3-23 and Ljubomirović 2018: 249-57. 
In the following nine decades, this claim by Saria would be repeated in many variations. Mano-Zissi and Mikulčić support Saria's claim, whilst Gebhard explains that the theatre at Stobi was abandoned because Theodosius I "put an end to all pagan festivals, closing the oracle at Delphi and the Olympic games." 11 Janakievski, whose work is still the most comprehensive study on ancient theatres in local scholarship, also supported Saria's theory; in addition, he introduced the alleged raid of Alaric's Goths in 395 as a possible factor for ending spectacles at the theatre in Stobi. ${ }^{12}$ Jakimovski and Surbanovska combine the theories set forth by Saria and Gebhard. They attribute the abandonment of the theatre to "Constantine's ban on gladiator games in 325, as well as successive bans of Theodosius I of all theatrical performances."13 The most recent works on the theatre at Stobi, authored by Gebhard and Pavlovski, agree that the theatre was converted during its second phase into a building suitable to host beast hunts and gladiatorial games, but do not mention the abandonment of the theatre and the reasons for it. ${ }^{14}$

Very similar opinions for the abandonment of the theatre at Scupi were voiced in the latest publication on the theatre of Scupi, a work dedicated to the 2012-16 excavations. ${ }^{15}$ The excavators attributed it to imperial edicts, and the aftermath of the battle of Adrianople in 378 and the raid of the Goths in $406 .{ }^{16}$ Here I would point out that by invoking so many different explanations for the same phenomenon is a logical contradiction. If the theatres were abandoned by an imperial edict, promulgated either in 325 or 395 , then there would be no reason also to attribute the abandonment of theatres to the aftermath of the battle of Adrianople in 378 or even to a later, fifth-century, raid. If the general situation after major battles and raids needs to be introduced into scholarship as a reason for the end of spectacles and the use of spectacle buildings, then one would expect that the effects of edicts were not sufficient by themselves to close the theatres. However, both theories keep

${ }^{11}$ All three authors led the excavations of Stobi during the American-Yugoslav project in the 1970s: Mano-Zissi 1981: 91 and Mikulčić 1999: 167. The latter cites the law explicitly as preserved in the Theodosian Code, CTh.12.12.1. Gerbhard led the excavation of the theatre during the 1970s and published extensively on the results. She does not cite either primary or secondary sources to support her claim regarding the abandonment of the theatre: Gebhard 1981: 18. The ban on the Olympic games and closing of pagan temples and festivals are discussed below.

12 Janakievski 1998: 157 and ibid. 1998: 15, who mostly cited the aforementioned work by Mano-Zissi.

13 Jakimovski and Šurbanovska 2007: 14-15, who cite chiefly Mano-Zissi and Mikulčić.

${ }^{14}$ Gerbhard 2018: 132-55, Pavlovski 2018:156-205.

15 Jakimovski 2017.

${ }^{16}$ Imperial promulgations: Jakimovski 2017: 11-29; Goths: Jakimovski, Jovanova, Ončevska-Todorovska, Jovanov and Pavlovski 2017: 29-118; hereafter, Jakimovski et al 2017. Vulić, the original excavator of the theatre in Scupi, did not elaborate on his reasons for the abandonment of the theatre. He focused on the small settlement that was erected above the abandoned theatre and its population. 
cropping up in even most recent scholarship, without the authors addressing the concurrent existence of two contradictory explanations.

Before we delve into greater detail in the discussion on the relationship between maintenance of spectacle buildings and spectacles themselves, as well as the religious aspect of spectacles and games, I shall present briefly the laws in question and illustrate how the presentation of the same information evolved within the timespan of the compilation of both Roman codes of law: the Theodosian Code in the midfifth century and the Code of Justinian in the mid-sixth century, and juxtapose them with an earlier source of a different nature, a panegyric text.

The most commonly cited law in this discussion is the promulgation of Constantine in 325 (no.1). This law was promulgated in Beirut as a regulation of gladiator fights and it is preserved in two late Roman codes and in a fourth-century panegyric by Eusebius of Caesarea. ${ }^{17}$ The Theodosian Code has a whole chapter on laws dealing with "Pagans, Sacrifices and Temples", of which a good third was promulgated by Theodosius I and his colleagues between 381 and $395 .{ }^{18}$ Only one author focused on the promulgations of Theodosius I as a reason for abandonment of theatres. ${ }^{19}$

Most of Theodosius I's laws are reiterations of laws promulgated by previous emperors and they enact a ban on sacrificing and usage of temples addressed to different officials throughout the empire, most probably responding to requests from these regions on how to deal with pagan phenomena in their midst. ${ }^{20}$ The law issued by Constantine in 325 , on the other hand, was a regulation of gladiatorial fights. ${ }^{21}$ In particular, this law applied not to games with professionally trained gladia-

${ }^{17}$ CTh.15.12.1, reiterated partially in CJ1.44.1 and Eusebius, Vita Constantini 4.25.1. Consulted translations for Eusebius: Schaft and Wace 1981, Cameron and Hall 1999 (in English), Beševliev et al 1954: 14-17 (in Bulgarian). Consulted editions and translations for Theodosian Code: Pharr et al 1957 (in English) and Dujčev et al 1958a: 260-87 (in Bulgarian); for Code of Justinian: Frier et al 2016 (in English) and Dujčev et al 1958b: 19-38 (in Bulgarian).

On Roman legislative pertaining to theatres and games, see especially Puk 2014, Gutsfeld and Lehmann 2013, Malineau 2002.

${ }^{18}$ Book 16, under title 10: CTh.16.10.7-12; CTh.19-24; Pharr et al 1957: 472-76.

${ }^{19}$ Gebhard 1981:18, where she claims that theatres were abandoned because Theodosius I ended spectacles, pagan festivals, divination at Delphi and the Olympic games. Around ten laws of Theodosius I could refer to any of these matters, but since the author provided no reference, I chose two laws as illustration only, as any further discussion would enter the realm of speculation without proper reference $C$ Th.16.10.9=CJ.1.11.2 and CTh.16.10.1; see Table 1, no. 4 and 5 respectively for full original text and English translation.

${ }^{20}$ Harries 1993: 82-6.

${ }^{21}$ The following laws from the same chapter are of similar nature, merely regulating participants in gladiator fights: CTh.15.12., banning people of senatorial rank from fighting as gladiators and CTh.15.12.3, bans persons from gladiator schools from serving in the Senate. 
tors, but to the practice of damnatio ad ludum whereby persons convicted of capital crimes fought to the death in the arena. Conversely, professional gladiators and venatores, whose training was an expensive and long process, rarely fought to the death. ${ }^{22}$ The edict of Constantine addressed these convicts and ordered fighting to the death to be replaced by a life sentence of hard labour in the mines (damnatio ad metalla). Therefore, this law did not prohibit gladiatorial games; it just regulated the participation of convicts.

One finds this law in the Theodosian Code, with a very clear legal formulation. The same law is also preserved in the Code of Justinian. Nonetheless, the formulation of the law here is truncated, ending after "we prohibit all gladiators". By the time the Code of Justinian was compiled and distributed, gladiatorial fights were rare enough for the distinction between professional gladiators and the damnati to have become blurred, but actual enough for some of the known legislation on them to be included in the new code. ${ }^{23}$

The third work that preserved this law is of a quite different nature from the legal codes; it is a panegyric dedicated to the emperor Constantine. The Vita Constantini was authored by Eusebius of Caesarea. In this work, written between 337 and 339, Eusebius wanted to conjure up an image of a pious Emperor, who was a benefactor both of Christianity and of the author. ${ }^{24}$ During the lifetime of bishop Eusebius, Christianity transformed from a persecuted cult to the official religion of the empire. ${ }^{25}$ Eusebius' Life of Constantine was a nod of gratitude and approval to the person Eusebius regarded as responsible for this turning of the tide. ${ }^{26}$ This is the thing that one needs to keep in mind when consulting Eusebius' panegyric: he was embellishing Constantine's acts as a devout ruler and the one to rectify the shortcomings Eusebius saw in paganism. ${ }^{27}$

Eusebius did consult imperial laws for his panegyric; in fact, his Book IV where one finds the relevant passage has the highest concentration of reference to laws. ${ }^{28}$ There is no information as to whether Eusebius consulted a rescript of the law or if he wrote from memory. However, he wrote a work which differs greatly from universal histories or codes of law. Panegyrics or enkomia by nature were works of praise. They were not meant to be objective records of reality, but aimed to glorify the personae of saints, emperors, and patriarchs. Kazhdan illustrates best the nature of the panegyric by observing that what is panegyric of one person can be an invective (psogos) against another. One

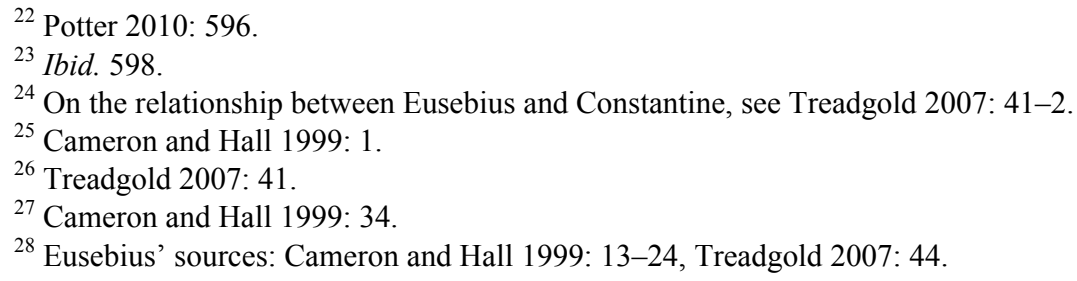


needs to be aware of the nature and purpose of the types of primary written sources one uses, as the very same information can be presented in different fashion with different goals in mind. ${ }^{29}$

Therefore, we have three sources that preserve the edict of Constantine: the Theodosian Code which holds the exact formulation of the law stating that it was meant for convicts condemned to fight in the games, the panegyric of Eusebius where the distinction between the damnati and professional gladiators is ambiguous at best, and the later Code of Justinian where the distinction between the two categories of arena fighters is non-existent. Such nuances provided by sources varying in nature, intent, and date of creation must be taken into consideration, because they tell us both the information and the context in which it was used. Even if we were to accept that the edict of Constantine did ban all gladiatorial shows, which is a dubious claim at best, it would not explain the ending of venationes, as animal hunts are attested well into the fifth century, as we shall see later on. Furthermore, imperial legislation did not also ban the ludi scaenici, the various theatrical shows which were the original purpose of theatres.

\subsection{The economic aspect: games, spectacles, and the maintenance of spectacle buildings}

Spectacles and the monumental architecture associated with them did not always go hand-in-hand. Many a show and fight did happen in the monumental buildings built and/or remodelled for these purposes, but performances could easily be given in temporarily constructed buildings of humbler and less impervious building materials as well. Mime actors and pantomime dancers performed in any location spacious enough to receive a wide audience: streets, fairs and festivals, markets, in private houses, and even in front of churches. Construction and maintenance of monumental buildings were matters of civic pride and careful management of the funds available to city councils from the city's budget, imperial support, and private patronage. Investment in the upkeep of the spectacle buildings or the lack thereof did not always overlap with a community's desire or ability to host games and shows. ${ }^{30}$

If we see both spectacles and spectacle buildings as dependent on the funds from civic councils and imperial and private munificence, it is

${ }^{29}$ Kazhdan 1991: 1570.

${ }^{30}$ On performance outside spectacle buildings and on impromptu stages, see Webb 2008: 25-6. On funding and upkeep of monumental buildings: Loseby 2007:143, Liebeschuetz 2016: 54-66, Jacobs 2013: 485-90, 525-31 and 536-545. On the process and persons involved in civic maintenance: Weiss 2014: 171-86, focusing on Palestine; Saradi 2006: 78-95 on civic maintenance in the works of Procopius, Malalas, Agathias, and Theophylact Simocatta; 151-63: project management by city councils; 164-73: funding by private benefactors, 174-9: financial responsibilities towards upkeep by provincial governors; 180-1: imperial patronage and 181-4: on the rising authority of bishops among the cities' proto $i$ and in urban construction and maintenance projects. 
crucial to examine how these providers fared. Loseby groups the changes that affected the available funds into two groups: external factors that limited the cities' self-governance and internal issues that affected the political and social culture of the cities from within. After the third century, the administrative machinery of the Roman state changed in a way that impeded the autonomy of cities and the steady flow of income in municipal budgets. The central administration absorbed civic lands and taxes diminished the steady income cities had at their disposition to manage their own projects. ${ }^{31}$

Two laws issued in 374 returned to the cities a third of their own taxes and of the rents of the lands they formerly owned. However, if the expenses of a project in a given city surpassed their third of taxes available, the governors of provinces were to repurpose a third of the taxes from another city to finish the project. ${ }^{32}$ The limitation imposed by the fisc on local budgets was still an issue in the sixth century, if we are to believe a passage of Procopius' Secret History. He informs us that shows at theatres, hippodromes, and circuses came to an end in the early years of Justinian's reign, because he appropriated to the fisc municipal funds used for the entertainment of the citizens and withdrew imperial support for local games, supporting only the consular games. ${ }^{33}$

The other, internal factor that Loseby mentions is the political and social changes that occurred within city councils. The upkeep of cityscapes that benefited greatly from the competitive munificence of the decurions was in decline as such obligations were becoming more and more financially burdensome. ${ }^{34}$ The provisions for games and maintenance of monumental architecture and amenities was mostly transferred to the provincial governors. ${ }^{35}$ To showcase the organisation and upkeep of spectacles and spectacle buildings, I have chosen the Pythian games and the Olympics. Both athletic competitions had a long tradition and

${ }^{31}$ Loseby 2007: 142-3.

${ }^{32}$ CTh.4.13.7 and CTh.15.1.8.

${ }^{33}$ Arc. 26.6-11, Nov. 105.1 (537), Miller and Sarris 2018. The nature of the Secret History might make this information seem dubious or at least, an exaggeration. There is no explicit comment on actually withdrawing funding from locally organised games, apart from the concluding sentence of the novel, informing us that these seven processions ought to be sufficient entertainment, as rarity is what makes entertainment appealing to the people.

${ }^{34}$ The flight of the curiales was an issue as early as Ammianus Marcellinus' days in mid-fourth century: Amm. Marc.19.8.6. There is a multitude of imperial laws that document the phenomenon during the fourth and fifth centuries: the Theodosian Code has a chapter named De Decorionibus (CTh.12.1-184). However, structural reforms from the late third century onwards tended towards damage-control than reversing existing trends; the same can be applied to issue of the flight of the decurions. On the complex relations between the central administration and the curial class: Loseby 2007: 143-6, Jones 1964: 543-4, 740-57, ibid. 1966: 282-4, Saradi 2006: 151-63, Lepelley 1979-81:67-72 and Liebeschuetz 2016: 5-6, 260, for their gradual replacement by the protoi.

${ }^{35}$ Upkeep: note 30 above, CTh.15.1 (passim); games: to be discussed below. 
same as gladiatorial shows, their end was attributed to imperial promulgations. ${ }^{36}$

Remijsen researched the origin of the connection between imperial laws and the Olympics. She argues that it could be traced back to the eleventh-century account Cedrenus, who garbled information from older accounts. ${ }^{37}$ Remijsen offers an interpretation of gradual abandonment due to a combination of factors, as observable in the archaeological record at Olympia. During the early part of the reign of Theodosius II (408-50), a fire destroyed the temple of Zeus at Olympia and the cult statue was moved to Constantinople. The temple was never renewed. Olympia became a Christian city in the fifth century, with a population that sustained itself mostly from agriculture. Blocks from the gymnasium gate, the palaestra, and statue bases from the nymphaeum went into the construction of a church at the former location of the workshop of Pheidias in the mid-fifth century. The baths near the Leonidaion were converted into a wine cellar. This transition might have been an initiative of the local population, led by their clergy, but the government might also have had a role in turning the temple land into farmsteads managed by tenants. ${ }^{38}$

In 424, the citizens of Delphi addressed Theodosius II with a complaint that they could not present at shows in Constantinople as they could barely afford the expenses for organising games in their own city. The emperor responded by lifting the compulsion of their participation in the capital's games. We do not know if the actual temple at Delphi was still active, but the Pythian games were probably ongoing. ${ }^{39}$ This law shows that providing for the games in Constantinople, organising games, and performances was a costly affair. Another law, one issued by Diocletian and included also in the Code of Justinian, informs us that the municipal funds for organising games were redirected to the repair of city walls by the provincial governor. Nonetheless, the emperor co-

${ }^{36}$ As shown in the discussion on the work of Gebhard on the theatre in Stobi. Other examples are mentioned later in this discussion.

37 The end of the Olympics was traditionally dated to 393 (by a promulgation of Theodosius I) in international scholarship in the late 1980s and 1990s, which correspond with the dates when most of Gebhard's work on the theatre in Stobi was published. See more in Weiler 1985-86: 54-7, idem. 1988: 112-19, Teja 1991 and Biscardi 1981:3 6778. Contra imperial abolition: Gutsfeld and Lehman 2003, Fargnoli 2003:119-54) and Weir 2004. All references collected from Remijsen 2015: 4, note. 46.

On Cedrenus: Remijsen 2015: 48, especially note 47 for the original text of Cedrenus in Greek. This author placed the end of the Olympics in the same period when Ambrose allegedly gave Christians clemency for burning down the synagogue at Constantinople; in fact, Cedrenus conflated the account on the fire of the synagogue of Callinicium on the Euphrates (modern day Al-Raqqa in Syria) in 388 with the information taken from the ninth-century account of Georgius Monachius on the destruction of the synagogue of Constantinople during the reign of Theodosius II (402-50). For iconographic sources for the agones and festivals associated with them, see Dunbabin 2017: 151-75.

${ }^{38}$ Remijsen 2015: 50.

${ }^{39}$ CTh.15.5.5, Remijsen 2015: 55-6 and Wier 200. 
vered the expenses for organising games, so the citizens could enjoy both "the safety of the new walls and the pleasure of the games."

The provincial governors, in an attempt to garner the approval of their citizens, were more interested in providing for prestigious projects and lavish games than to do patchwork repairs of already existing buildings. ${ }^{41}$ Their extravagance paid from the public coffers reached such levels that Theodosius and Honorius proclaimed a law which banned governors from importing chariot horses and drivers, animals or actors from another city for this purpose. ${ }^{42}$ Provincial governors were also banned from stripping marble decorations from smaller cities as to reuse them for projects in the provincial capitals where they resided. ${ }^{43}$ In 498, Anastasius banned fights in the arena to cut the expenses on lavish arena spectacles. ${ }^{44}$ The last venatio recorded was on January $1^{\text {st }}, 537$ in Constantinople. ${ }^{45}$ We have already mentioned the information from the Secret History that Justinian meddled with the organisation of local games and supported only the seven consular processions. ${ }^{46}$ While some theatres were maintained and active in the sixth and even in the early seventh century, as will be illustrated in the following discussion in this article, it is clear that the expenses of organising games and performances were becoming too dear even for the imperial élite.

The high cost of organising games and spectacles was one of the main factors why theatres became what Loseby calls "urban behemoths, colonised by housing, quarried for materials, or left to slow decay.", 7 This did not happen with the same pace and at the same time everywhere in the empire. Some theatres fell into disrepair as early as the fourth century, others were maintained, adapted and used well into the sixth century. Theatres in large cities and provincial capitals fared better, as they benefited from support from the emperors and provincial governors and functioned well into the sixth century. ${ }^{48}$ Major city centres were more likely to have local élites willing and affluent enough to invest in their upkeep. Some theatres suffered in earthquakes and were never repaired. Theatres in good condition were repurposed and incorporated

${ }^{40}$ CJ11.42.5 (286-305), Frier et al 2016.

${ }^{41}$ Loseby 2007: 143. Saradi notes that the responsibility for civic maintenance in the East was transferred to provincial governors as early as the first half of the fourth century, as documented by inscriptions. One century later, the prov. governors were the primary carriers of public works in the cities, as documented in the Theodosian Code (XV.1, De operibus publicis): Saradi 2006:174-5, esp. note 907-12, Lepelley 1979-81: 61-4, Di Segni 1995: 317-23, Weiss 2014: 249, 253.

${ }^{42} C J 11.41 .5$ (409).

${ }^{43}$ CTh.15.1.14 (365).

${ }^{44}$ Lee 2008: 54, Joshua the Stylite, Chronicle 34 and 46, to combine this information with the discussion on the Brytae festival in notes 51 and 80 .

${ }^{45}$ Bomgardner 2000: 219.

${ }^{46}$ Notes 30 and 35 above.

${ }^{47}$ Loseby 2007: 151.

${ }^{48}$ Saradi 2006: 319, Jacobs 2019: 111-44. 
in other buildings or dismantled to reuse their stone in other building projects. The theatre at Phthiotic Thebes is an interesting one: the inhabitants of the city moved to another site, Nea Anchialos, in late antiquity. Instead of building a new theatre in their city, they kept using the theatre of the old city well into the fourth century.

The theatre at the Antiochene suburb of Daphne was restored in 341 after an earthquake and was used until the last decades of the sixth century. ${ }^{50}$ In 529, Justinian banned spectacles in Antioch after a riot and closed the theatre, but he did renew it after it was destroyed in a fire. ${ }^{51}$ The theatres at Ephesus and Aphrodisias were used in the sixth century. ${ }^{52}$ Their counterparts at Caesarea Maritima and Petra were renovated during the late fourth of fifth century. Later on, the theatre at Caesarea Maritima was incorporated into the new intramural fortress sometime during the late sixth or early seventh century. ${ }^{53}$ We have earlier examples of a similar practice, such as the theatres of Spoleto and Sparta. ${ }^{54}$ The theatre at Demetrias was abandoned in the mid-fourth century and by the fifth century blocks from its cavea were used to build the synthronon of the Cemetery Basilica. More than 200 seats of the theatre at Epidaurus went into the construction of the city's early Byzantine fortification walls. ${ }^{55}$ At the city of Side, the ecclesiastical capital of Pamphylia Prima, the pillars and vaults of the theatre were repaired in the fifth or sixth century, with the patronage of Phronton and Theodoros, magistrates of the city. The donor inscriptions found at the theatre shows that there were still representatives of the local élites willing and able to donate to the maintenance of public buildings. ${ }^{56}$

Theatres damaged by earthquakes were more often dismantled for building material than repaired. Saradi informs us that the stage building at the theatre at Corinth most probably collapsed in the earthquake of 375 and by the late fourth century parts of the theatre were reused in the restoration of the city walls. The theatre at Butrint in Epirus Vetus probably suffered in an earthquake in the mid- or late-fourth century; the fallen statues of the scaenae frons were found in situ. Furthermore,

${ }^{49}$ Saradi 2006: 321.

${ }^{50}$ Ead. 2006: 319, especially note 1800.

${ }^{51}$ Saradi 2006: 31, Jacobs 2019: 111-44. Cf. with the renewed theatre at the Daphne after an earthquake and temple of Zeus at Olympia, which was also destroyed by fire, but not renewed. On the religious element and how the level of successful disentanglement of the pagan past of a given building had effects on its preservation, see the following section in this article. Also $c f$. with the Brytae in Constantinople, where Emperor Anastasius was forced to exile members of the circus factions in 502 and the faction rivalry that triggered the Nika riots in 532 in note 80 below.

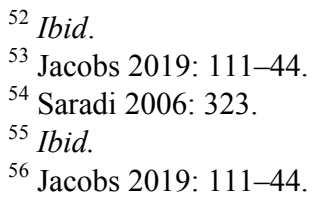


the terraces above the theatre that supported the slope also collapsed and the theatre ended up covered in washed down rubble. ${ }^{57}$

This small dossier on the fate of spectacle buildings across parts of the eastern Roman empire paints a picture of theatres in major cities faring better because of the presence of local élites willing and affluent enough to invest in their upkeep. Some theatres suffered in earthquakes and were never repaired. Theatres in good condition were repurposed and incorporated in other buildings or dismantled to reuse their stone in other building projects. Finances certainly had a crucial role on this redesign of urban space, but they are far from being the sole factor. We know that the theatres from Scupi, Stobi, and Heraclea in modern-day North Macedonia had several construction phases, that speak of their renewal and modifications for different types of arena performances. After their abandonment, they shared the same fate with many theatres across the empire: they were dismantled and their stone was reused in other projects in their respective cities or in the vicinity. This shows, especially for the city of Stobi, the change of priorities when it came to construction of new buildings and the maintenance of old ones, as almost all buildings in which parts of the theatre were reused were of ecclesiastical nature. The following section in this article focuses on the religious dimensions of spectacles and spectacle buildings and how they helped in redefining the late antique cityscapes. We shall return to the fate of the Macedonian theatres towards the end of this article.

\subsection{Overlapping spheres in late antique cities: the pagan, the secular, and the sacred}

The late antique city of Stobi had at least six churches; three intramural and three extramural ones. ${ }^{58}$ The city also had a thriving Jewish community, and a temple dedicated to the Egyptian goddess Isis. Stobi was also a place where the cult of Dionysius, the patron of the theatre, was very strongly respected. ${ }^{59}$ The temple of Isis and the Synagogue were both in use during the second century. The Synagogue had at least two construction phases and was converted into a church in the beginning of the fifth century; by this time two other intramural basilicas were constructed. ${ }^{60}$ The temple of Isis might have been in use until the turn of the fourth and fifth centuries. We do know that by the mid-

${ }^{57}$ Corinth and Butrint: Saradi 2006: 320. We can infer the magnitude of this earthquake by the fact that the damage of the theatre was discovered intact. Also, Butrint is not listed among the eleven cities of Epirus Vetus in Hierocles' Synecdemos 651.4-652.6.

58 Intramural: The Northern Basilica, the Episcopal Basilica, and the Synagogue/Central Basilica; extramural: Basilica Extra Muros, the Cemetery Basilica and the Basilica Palikura.

59 Temple of Isis: Blaževska and Radnjanski 2015: 215-56; Synagogue: Ovadiah 2015: 211-27, Marmorstein 1937: 373-84; Jewish-Christian relations: Koltun-Fromm 2009: 556-71; Cult of Dionysius: Nikoloska 2015a: 87-96, ead. 2015b: 83-106.

${ }^{60}$ Ovadiah 2015: 211-27 and Marmorstein 1937: 373-84. 
fifth century it was partitioned into a residential complex and partially dismantled. ${ }^{61}$

These finds highlight that Stobi had three contemporaneous religious communities and their edifices shared a prime location within the city's borders and all of them gravitate around the Roman theatre. ${ }^{62}$ Even though all these religious building share the same focal urban space, local scholarship focused on the relationship between the Episcopal Basilica and the theatre. Namely, the Old Episcopal Basilica was built just to the west of the theatre in the first half of the fourth century. It would later be torn down, the ground level raised, and the New Episcopal Basilica would be built on the artificial platform thus created in the mid-fifth century, thereby encroaching onto the peripheral wall of the abandoned theatre. Since it was built on an elevated level, the New Episcopal Basilica had a much more dominant position than the Old one.

Much thought has been given to the location of these two basilicas. The first excavators of the Old Episcopal Basilica thought that the location was chosen close to the theatre because the church was built in honour of the Christians who were martyred in the theatre. ${ }^{63}$ Saradi believes that construction of Christian chapels in stadia, theatres, amphitheatres and hippodromes where martyrs suffered their martyrdom marks the profound Christianisation of these buildings. ${ }^{64}$ Nonetheless,

${ }^{61}$ Blaževska and Radnjanski 2015: 255-6.

62 The Episcopal Basilica and its residence, as well as the Synagogue and the third intramural church communicate directly with the Via Sacra, the main thoroughfare of Stobi. The temple of Isis is located below the theatre and probably by the time the second phase of the Old Episcopal Basilica was erected and the Synagogue was converted into a church, was out of commission and transformed into a residential area.

${ }^{63}$ Egger 1929a: 14-44, idem. 1929b: 42-87, Saria 1933: 11-22, Wiseman 1984: 295, Hoddinott, 1963: 136-7, Aleksova 1995: 291-4, and Mikulčić 1999: 314; Blaževska and Tutkovski 2012: 9-12 and Vesevska 2018: 363-73.

It bears mentioning that a crypt was discovered in the apse of the Episcopal Basilica. The two construction phases were not clearly delineated until the excavations led by Aleksova in the 1970s, so it is possible that this crypt was interpreted as a martyr's burial. Later on, when it was defined that there were two construction phases and that the crypt, bearing the remains of an adult man, chronologically belongs to the New Episcopal Basilica, this burial in the altar was interpreted as belonging to one of the church's bishops, see note above.

${ }^{64}$ E.g., north of the agora in Thessalonica we find the stadium where St. Nestor was martyred and was commemorated with a shrine dedicated to him. In the amphitheatre of Salona, two sixth-century oratories were placed in the space near the theatre that was previously used for the cult of Nemesis; one of these oratories bore the fresco of St. Asterius, who was martyred among others in this amphitheatre. A chapel was built near the amphitheatre in Dyrrachium, attributed to St. Asteios who was martyred there. A church was built in the auditorium of the theatre of Side in Pamphylia in the fifth/sixth century, where nine Christians were fed to the beasts under Diocletian. Chapels were built near spectacle buildings even if there was no known connection to a martyrdom, such as the theatre of Dionysius in Athens, where a church was built in the late fifth century in the eastern parodos. On the site of the theatre of Samos a church was built during the rule of Justinian I, see Saradi 2006: 301, 321. An oratory was added to the theatre in Aphrodisias and two 
there is neither literary nor archaeological evidence that hints at Christians having been martyred at the theatre of Stobi. Furthermore, the elevated position of the New Episcopal Basilica, looming over the dilapidated theatre and dominating the cityscape, was taken as a final triumph of Christianity over paganism. Similar sentiments were voiced about the theatres in Scupi and Heraclea. ${ }^{65}$

If we see the urban space presented as such, it would seem there is a very strong pagan-Christian dichotomy. However, the Christianisation of late antique cityscapes was always a work in progress and according to several ancient authors, the late Roman cities never transformed completely to Christian values. ${ }^{66}$ Instead of focusing the discussion on the triumph of Christianity over paganism, Lim underlines the importance of analysing the late antique debate among Christian authors on what can be considered as pagan (an umbrella term for all beliefs, rituals, and practices that had no place in a Christianised world), what was Christian, and what belonged to both and neither in the same time: the secular. ${ }^{67}$

Roman society had a long tradition of cultural and social institutions that did not sit well with the viewpoint of many Church fathers of what ought to be the ideal Christian society. One such tradition consisted of the shows and spectacles: gladiatorial combats (munera), animal hunts (venationes), theatrical performances (ludi scaenici) and chariot races (ludi circenses). However, even among the paragons of Christian thought, there was no consensus on their status. Some saw them as clear manifestations of pagan practices; others observed them as part of the unsanctified world. The School of Gaza and the work of its scholars shows a deep appreciation for classical culture even among Christians in the late fifth and the first half of sixth century. ${ }^{68}$ This process of constant revaluation created a buffer zone in the form of secular space where select cultural practices, games and shows among them, could exist. ${ }^{69}$ The games and shows themselves had to undergo a series of transformations to fit in these constantly redefining lines.

small chapels to the theatre at Side, where nine saints were martyred during the reign of Diocletian, see Jacobs 2019: 111-44.

${ }^{65}$ Mikulčić 1999: 314. Vesevska 2018: 363-73 interprets the building of Early Christian church complexes next to the theatres in Scupi, Stobi, and Heraclea Lyncestis as honouring Christian martyrs who allegedly perished in the arenas of these cities. However, the author herself (ibid., 368) mentions that only the Basilica with a Double Apse in Scupi contains a possible martyr's grave. There are no indications whatsoever that the person buried there was martyred in the theatre.

${ }^{66}$ Lim 2009: 497, 500-1; also, MacMullen 1984, DeVoe 1978, ibid. 2002. and Webb 2008.

${ }^{67}$ Lim 2009: 497, Jacobs 2014a: 192-219, Jacobs and Waelkens 2017: 175-98.

${ }^{68}$ E.g.: Choricus of Gaza defended the educational and entertainment value of mimes against the attacks of Christian theologians: Jacobs 2019: 111-44 and Webb 2008: 11638.

${ }^{69}$ Lim 2009: 497, French 1985. 
The Christian leaders did focus on removing the most obvious signs of the old pagan religion, that is, the blood sacrifice of animals and cults worshipped in temples and shrines. ${ }^{70}$ Imperial concession was made to these demands, as a whole chapter in the Theodosian Code informs us, among other sources. ${ }^{71}$ Indeed, Christian authors, as illustrated previously with Eusebius and the ban of 325, used the long list of bans on temples and sacrifices as an illustration of the triumph of Christianity over paganism. However, this definition of what is pagan is not originally Christian. Lim points out that this is an imperial construction of paganism, which was focused mostly on cults worshipping various gods and their divine statues by presenting them with blood sacrifice. As such, the imperial authority could and did negotiate and facilitate, from the time of Constantine onwards, the creation of pagan, Christian, and secular as categories.

If one removes the elements of worship and blood sacrifice, the practice could not be labelled as belonging to the old, pagan religion and thus, nonconformative to the Christian values. By removing the religious elements from shows and spectacles, they were transformed into secular entertainment. In 425, Theodosius II and Valentinian banned theatrical amusement and spectacles in the circuses on Sundays and on major Christian holidays; this is the only imperial concession in legal form to Christian religious sensibilities towards shows and spectacles in the fifth century. ${ }^{72}$ Theatres were so embedded in the culture and representation of cities, that we find the theatres of Gaza and Naples depicted on the Map of Madaba, a mosaic that graced the floors of a church. ${ }^{73}$

When it comes to representations of theatres and persons of the stage, Webb makes a compelling juxtaposition of two very different and roughly contemporaneous representations of empress Theodora. On the mosaics in San Vitale, we have Theodora as a generous patron and a pious Christian ruler; whilst in Procopius' Secret History, we have a description of the young Theodora giving a lewd mime act on the stage. We do not know when and if the Secret History was circulated, but the theatrical career of Theodora was public knowledge and yet, she was considered fit to be an imperial consort and as such, represented in a church. Webb also stresses that the disdain that some members of the intellectual élite had for theatre and theatre performers pre-dates Christianity and that in his description of Theodora, ${ }^{74}$ Procopius drew on a

${ }^{70}$ Busine 2013: 325-45, who raises the possibility that stories on Christian destruction of pagan temples might have been embellished and exaggerated in order to achieve a greater effect of triumph over paganism.

${ }^{71}$ Notes 17 and 18 above.

${ }^{72}$ Jacobs 2019: 111-44.

${ }^{73} \mathrm{Ibid}$.

${ }^{74}$ Secret History 9.20-23. On the authenticity of the Secret History, see note 33 above. On Theodora, see Webb 2008: 4-6, especially notes 6-7 for primary sources on the treatment of theatre performers by pagan authors. 
long literary tradition of depicting theatre performers as not suitable for the standards of society.

In entertainment buildings that had prolonged usage, attempts were made to dissociate the pagan past, by removing or adapting the stillstanding marble decoration. At Aphrodisias, a representation of Aphrodite was removed from the marble relief decorating the stage building, a treatment not limited only to the theatre building in this city. ${ }^{75}$ Both of the aforementioned theatres at Caesarea Maritima and Petra were renovated in the late fourth or the fifth century, but the niches where once statues stood in the scene building were now filled with rubble and blocked by walls faced with marble revetments. ${ }^{76}$ The statuary at Ephesos remained in place, but not intact. Pagan statuary was found on prominent display elsewhere in late antique cities, such as the colonnaded street in Sagalassos. The context of these finds suggest that they were on display as late as the seventh century, after they were reused during a major renewal project in the lower town.

One way to accommodate the theatre in the Christian sphere was to apply crosses on the outside and the inside of the theatres. We find such examples at the theatres at Side and Perge. The theatre at Stobi bore crosses on its seats, carved together with the personal names and phylae. They are dated to the late second and early third century, which suggests that Christian audience was entertained at the theatre of Stobi in the same time of the alleged imperial bans. ${ }^{78}$ At the theatre of Aphrodisias, prayers were carved on the front wall of the scene building and on the theatre seats. In addition, at the beginning of the sixth century, when stage shows were still performed in the theatre at Aphrodisias, two rooms flanking the scene were redecorated. The north room probably served as an oratory, as it bore frescoes depicting the archangels Michael and probably, Gabriel. ${ }^{79}$

Pagan myths were not only told through statuary, but also through theatrical shows and mimes. We know that three festivals that involved theatrical performances continued to take place in Constantinople, Antioch-on-the-Orontes, and Edessa, the metropolis of Osrhoene, at

${ }^{75}$ This city had a prominent cult of Aphrodite. In the seventh century, the city was renamed to Stauropolis (City of the Cross) as to cut ties with the pagan cult, see Jacobs 2019: 111-44.

${ }^{76}$ Examples from private residences at Stobi: The niches of the peristyle courtyard at the Theodosian palace of Stobi displayed older pagan statuary well in the fifth century, the fountain of the House of Psalms had a later, walled-in niches, suggesting that it originally served the same purpose.

${ }^{77}$ Jacobs 2016: 93-117, Babamova 2018b: 269-70.

${ }^{78}$ On the practise of using crosses as an agent of Christianisation of classical cities, see Jacobs 2017:175-222.

${ }^{79}$ Ibid. See aslo Jacobs 2016: 3-117, Jacobs and Stirling 2017: 196-226 and Stirling and Kristensen (eds.) 2016, especially Alexandrescu 2016: 243-65 on the fate of sculptures in the Lower Danube region and Burkhardt 2016: 118-50 on the reuse of ancient sculpture in late antique Athens. 
least until the beginning of the sixth century. They are attested through laws, the writings of contemporary authors, and epigraphic evidence. ${ }^{80}$ If pagan festivals that involved theatrical shows and mimes retelling pagan myths lived on in major cities and important Christian centres, it can be suggested that smaller cults and their festivals survived as well.

These examples show the intricate dance between imperial, ecclesiastical, and urban élites that created the late antique cityscapes. Concessions were made by all sides and of course, each side had its polar opposites in representing their interests, ranging from the laxest ones to the zealots. Lim and Webb both rightfully point out that modern scholars must take into consideration, when consulting the Patristic authors on their treatment of spectacles, that they represent but one facet in a complex dialogue. ${ }^{81}$

We come back to the issue of the relationship between the New Episcopal Basilica at Stobi and the theatre. If we take into consideration the discussion on creating blended/overlapping spaces in late antique cities and the practicality of managing and funding projects, we can suggest other answers for the location of the church. After the theatre was abandoned, many of its marble seats were reused in subsequent projects around the city. We find marble seats in the construction of the new east city wall, North Basilica, Porta Heraclea, Via Sacra, Via Episcopalis, and New Episcopal Basilica. All the locations where parts of the theatre

${ }^{80}$ All three festivals involved theatrical performances and revels near water and were perceived as licentious. It might have been one feast with regional variations or three different festivals which had similar elements; only the Maiuma is well-documented: Greatrex and Watt 1999: 1-20 and Segal 1995: 11-13.

On the Brytae in Constantinople: banned in 501/2 when Anastasius as a response to the previous-year celebration which ended in bloodshed and involved the dancer factions of Constantinople, see John of Antioch, Fragmenta Historicum Graecorum fgr. 214c (5th c.), Marcellinus Comes, Chronicle 501.1-3 (6th c.), John Malalas, Byz. History 39 (6th c.) and the Souda III.309.47 (10th c.).

On the festival of water in Edessa: night revels near water lasting for three days and mime performance, attested in 496, 498 and 499, before being banned in 502, see Joshua the Stylite, Chronicle 27, 30 and 33 (6th c.).

On the Maiumas in Antioch: celebrated every three years with a theatre-night event, in the second c. it was funded by the state, then banned by Constantine and revived by Julian the Apostate. Under Honorius and Arcadius it was allowed under the condition that they were kept "modest and in respectable manner" $(C T h .16 .6 .1,396)$ and when that condition was not met, it was banned but theatrical arts were still allowed (CTh.16.6.2, 399). Nonetheless, as CTh.16.6.1 (=CJ11.46.1) is included in the Code of Justinian, the festival was reinstalled sometimes during the 6th c., see Frier et al 2016: 2725, note. 139; other sources on the Maiumas: Julian the Apostate, Misopogon (362), John Malalas, Byzantine History 284-85 and 362.18-21 (6th c.), John the Lydian informs that revellers from Rome travelled to Ostia to enjoy the water revels, De mensibus IV.80 (6th c.); on epigraphic evidence attesting the Maiumas in Nicaea, Aphrodisias, Heliopolis and Gerasa, see Greatrex and Watt 1999: 10-12 and Wilson 2016: 77-90. $54-57$.

Pagan cults in the Balkans: Saradi and Eliopoulos 2011: 261-310, Murlyan 2011:

\footnotetext{
${ }^{81}$ Lim 2009: 501-3, Webb 2008: 8-9.
} 
were reused are in its vicinity. In the case of the New Episcopal Basili$\mathrm{ca}$, the theatre served as a quarry of high-quality stone was just a stone's-throw away. The marble decoration of the old Episcopal Basilica was carefully dismantled and reused; it would be common sense to do it with the available material from the theatre.

Furthermore, the location was alongside one of the main thoroughfares of the city, the Via Sacra, which led from the main city gate, the Porta Heraclea, towards the city centre. The Via Sacra was a colonnaded street that widened in front of the Episcopal Basilica, forming a semi-circular plaza, which was also colonnaded and contained several shops. All these elements made for the urban core of Stobi in the fifth and sixth centuries, which gravitated around the main church in the city and which had a convenient plaza for gathering next to it. Therefore, I suggest that the location of the Old and New Episcopal basilicas was one of practicality. ${ }^{82}$

\section{The archaeological evidence for the abandonment of the theatres at Stobi, Scupi, and Heraclea Lyncestis}

Three theatres from North Macedonia will be examined in this section. All three were located in major urban centres. Two of these cities were provincial capitals: Scupi of the province of Dardania, and Stobi of Macedonia Secunda. Heraclea Lyncestis was a prosperous city in Macedonia Prima. Stobi and Heraclea Lyncestis have their origin in pre-Roman times; Scupi developed out of a castrum of the Roman army. ${ }^{83}$ All three cities prospered under Roman patronage: Stobi and Heraclea were granted municipal rank, while Scupi was a colonia. As provincial capitals, Stobi and Scupi were probably metropolitan sees, while Heraclea was a bishopric.

It is traditionally held that these cities were abandoned by the sixth or early seventh century: the end of Stobi and Heraclea is usually attributed to the Avaro-Slavic raids of the late 580s, while Scupi is said to have suffered in a devastating earthquake in $518 .^{84}$ The theatres in these cities share a similar fate with each other, as well as with numerous other theatres across the empire. At some point after their abandonment their high-quality stone was reused in various projects in their respective cities and their vicinity and/or the area of the dismantled theatres was used for dwellings, usually of humbler character. These settlements were usually treated by the original excavators as "late antique" or "Byzantine", without much regard for their stratigraphy and chronology, neither during excavations nor in subsequent publications. They

82 On the arrangement of the New Episcopal Basilica, the Via Sacra and the sigmaplaza: Jacobs 2015a: 74-114; commercial activity: Nikolovski 2018: 308-41.

${ }^{83}$ Mikulčić 1999, Jakimovski 2017, Babamova 2018a and 2018b, also the four volumes of the Studies in the Antiquities of Stobi

${ }^{84}$ Mikulčić 1999, 1996 and 1982; Jovanova and Ončevska-Todorovska 2017: 22-3. 
are usually taken as a sign of the end of prosperous cities, expressed in the appearance of huddled houses of stone and mud. All three theatres have been discussed at great length in existing publications; here I offer a short overview of their fate during- and post-abandonment.

The theatre at Stobi was built during the mid-second century and functioned at least to the late fourth century. Its cavea accommodated up to 7,000 spectators and had a diameter of $90 .^{85}$ The theatre was built with mixed elements of the Greek and Roman types of theatres. ${ }^{86}$ The building shows subsequent modifications that would allow for combat spectacles, with elements adapted from amphitheatres. ${ }^{87}$ By the third century, beast hunts and fights were organised here, as we are informed by an inscription witnessing an invitation ad munera issued by the high priestess of Stobi ${ }^{88}$ Sear finds this transformation of theatres into dualpurpose edifices typical for Greece and Asia Minor, usually occurring in the second and third centuries. The same transformation is noticeable at the theatres of Ephesus, Aphrodisias and Side, as well as the Acropolis theatre at Pergamum. ${ }^{89}$ Stadia, when no longer in use, were also converted into amphitheatres, such as the stadia at Gerasa, Caesarea Maritima, Neapolis and Scythopolis. ${ }^{90}$

The theatre was surely abandoned at some point before the beginning of the fifth century, when parts of it were reused in new building programmes. Most of the projects in which building elements of the theatre were reused date to the fifth century, though there is always the possibility that the theatre was abandoned long before its dilapidation. ${ }^{91}$ The abandonment and subsequent dismantlement of the theatre at Stobi was followed by the building of a humble settlement of stone and mud dwellings on top of the orchestra and the radial walls.

The theatre at Heraclea was constructed during the first two decades of the second century. This spectacle building was built on a smaller scale, but of similar construction as the theatre of Stobi. Both theatres have seats elevated above ground level, lack a permanent stage, and had a protective barrier for the first rows of the seats. Unlike the remodeled theatre at Stobi, the theatre at Heraclea was built from the very begin-

${ }^{85}$ Gebhard 1981: 13. This work remains the crucial one for the abandonment of the theatre. History of excavations of the theatre: Mano-Zissi and Wiseman (eds.) 1973, Mano-Zissi and Wiseman (eds.) 1975, Aleksova and Wiseman (eds.) 1981; latest research: Gerbhard 2018: 132-55, Pavlovski 2018: 156-205.

${ }^{86}$ Dyggve 1958: 137-57.

${ }^{87}$ Gebhard 1981: 13. Similar modifications noted at the theatres of Tyndaris, Cyrene, Dodona and Corinth, see Gebhard 1981: 61 and Sear (2006): Tyndaris (pg. 44 and 194, Plan. 117, Pl. 51), Cyrene (pg. 290, Plan 262, Pl. 91), Dodona (pg. 411, Plan 433, Pl. 141) and Corinth (pg. 392, Plan 419).

${ }^{88}$ Three days of beast hunts and fights funded by the archieria Tiberia Claduia and her husband: Babamova 2018: 111-31.

${ }^{89}$ Sear 2006: 42-4.

${ }^{90}$ Saradi 2006: 297.

${ }^{91}$ Hattersley-Smith 1996: 56-7 and Wiseman 1984: 289-314. 
ning to host beast hunts and fights. ${ }^{92}$ It was abandoned at some point before the end of the fifth century. There is no information on its development and usage up to the point of abandonment. The terminus ante quem is the construction of the Large Basilica in the late fifth or early sixth century, which so far is the only excavated building in which parts of the theatre have been reused. ${ }^{93}$ After the theatre was abandoned, the orchestra was used as a dump and as a stone quarry. ${ }^{94}$ Above the deposits of the orchestra, humble dwellings were found and coin-dated to the mid-fifth century. ${ }^{95}$

The theatre at Scupi lies in the western section of the city, where the natural slope of a hill was used to bear the construction. The suggested dates for building the theatre vary between the end of the first century and the first half of the second century. The auditorium was so thoroughly dismantled after abandonment that only the supporting vaulted corridors and foundation of the scene remained in situ. The theatre had a parapet that separated the orchestra and the first row of seats. This passage was accessible through several entrances, which also served as refuge access during combat spectacles. ${ }^{96}$ There is no information about the exact point in time or the reason why the theatre was abandoned. After it was abandoned, dwellings built from reused stone and mud spread over the arena, the stage building, the lower and upper sections of the cavea and right outside the last radial wall of the theatre. According to Ončevska Todorovska, this settlement was already erected by the end of the fifth century. ${ }^{97}$ There is a layer of debris a metre thick, containing fragments of marble decoration belonging to the scene building's façade, between the floor of the arena and the floor level of the settlement. Therefore, the theatre was abandoned well before this settlement was established, if this thickness of debris had already accumulated.

The evidence examined in this section offers no support for the idea that theatres in North Macedonia were abandoned because of imperial edicts; neither the primary written sources nor the archaeological evidence confirm this notion. Most of the laws consulted on matters pertaining to spectacles and spectacle buildings date to the third and fourth centuries, though many later reiterations followed. Furthermore, imperial laws and other primary written sources inform us that venationes continued through the fourth and fifth centuries, and those other forms of non-combat entertainment continued in theatres long after this. The archaeological evidence shows that many theatres saw prolonged use well into the sixth century. The theatres in North Macedonia were used well into the fourth century and they either show adaptations to

\footnotetext{
92 Janakievski 1998: 128, ibid. 1975: 165-72.

93 Janakievski 1998:13 and Hattersley-Smith 1996: 90. Both authors accept the dating by Tomašević 1965 .

${ }^{94}$ Hattersley-Smith 1996: 90.

95 Janakievski 1998: 163.

${ }^{96}$ Jakimovski et al. 2017: 55.

${ }^{97}$ Ončevska-Todorovska 2017: 245-321.
} 
buildings suitable for combat shows or were conceptualised from their initial constructions to host beast hunts and gladiatorial fights. They were dismantled and repartitioned sometime around the fifth century, though we cannot say how much time elapsed between their abandonment and the subsequent reuse.

The abandonment of entertainment buildings cannot be isolated from other changes observable in the cityscapes of the period and explained away neatly with an imperial law. Rather, I believe that examining the long-term changes in a city and the nature of the factors that prompted these changes, whether financial, social, religious or practical in nature, offers a better understanding of the cycle of usage of certain types of buildings and what that can tell us about the overall urban development of late antique cities.

\section{Conclusion}

The local scholarship on Roman theatres in North Macedonia still extensively uses late antique laws to explain the abandonment of spectacle buildings. When examined more thoroughly, in an attempt to understand how these laws came into being and how they were preserved, it becomes apparent that these laws do not reflect any explicit or implicit bans on theatres and gladiatorial games. Even when explicitly promulgating a ban, the central Roman administration did not have the means to enforce it, apart to expect that local parties who had an interest in their enforcement would take care of it. Most laws preserved in Late Roman codices show regional diversity in approaching many issues, especially those of a religious nature. Furthermore, we can say that through the promulgation of imperial edicts, among other media at their disposal, emperors participated in and facilitated the discussion on forming overlapping spheres of the pagan, the secular, and the sacred, where old traditions were redefined and blended with new Christian values and thus, made acceptable to all parties interested. Spectacles and spectacle buildings were in decline, but it was a slow process which did not happen at the same pace all over the empire. Imperial influence was more felt in restrictions on funding of imperial and local games and the maintenance of spectacle buildings than by strict bans. The matter of shifting patronage to other, ecclesiastical projects also took a toll on the providing for entertainment and the upkeep of entertainment buildings.

The analysis of archaeological evidence, as it is available in publications, does not show anything extraordinary going on in North Macedonia. Similar phenomena took place throughout the empire. Some theatres fared better than others, especially those built in politically and economically more powerful cities. Some collapsed due to natural disasters. Some, like the theatres in North Macedonia, were abandoned and their stone reused for other building projects, such as churches, which slowly became the prime projects to be supported by central administration, clergy, and local élites alike. 
TABLE 1. Original sources on combat spectacles and their translations (by author, after Cameron 1990, Pharr et al. 1952, Frier et al. 2016, Potter 2010, Babamova 2012)

\section{AD 325: Theodosian Code 15.12.1:}

Imp. Constantinus a. Maximo praefecto praetorio.

Cruenta spectacula in otio civili et domestica quiete non placent. Quapropter, qui omnino gladiatores esse prohibemus eos, qui forte delictorum causa hanc condicionem adque sententiam mereri consueverant, metallo magis facies inservire, ut sine sanguine suorum scelerum poenas agnoscant.

Proposita Beryto kal. octob. Paulino et Iuliano conss. (325 Oct. 1)

(Potter 2010: 597)
Imperator Constantine Augustus to Maximus, Praetorian Prefect

Bloody spectacles do not please us in civil ease and domestic quiet. For that reason we forbid those people to be gladiators, who by reason of some criminal act were accustomed to deserve this condition and sentence. You shall rather sentence them to serve in the mines so that they may acknowledge the penalties of their crimes with blood.

Posted at Beirut on the Kalends of October (October 1) in the consulship of Paulinus and Julianus (325).

(Potter 2010: 597)

...Bloody spectacles displease Us amid public peace and domestic tranquility. Wherefore, since We wholly prohibit the existence of gladiators, You shall cause those persons who, perchance, on account of some crimes, customarily sustained that condition and sentence, to serve rather in the mines, so that they will assume their penalty for their crimes without shedding their blood...

(Pharr et al. 1952: 436)

\section{AD 337-339: Eusebius' Vita Constantini 4.25.1:}

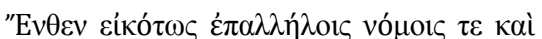

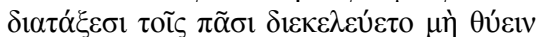

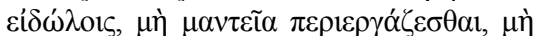

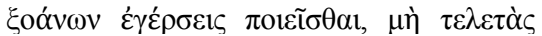

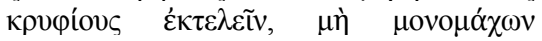

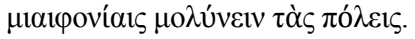

(Potter 2010: 597)
"Hence, in successive laws and ordinances, he suitably forbade everyone from sacrificing to idols, practicing divination, erecting cult statues, performing secret rites and polluting the cities with the bloodshed of the monomachoi."

(Potter 2010: 597)

"Hence it is not surprising that in successive laws and ordinances he prohibited everyone one from sacrificing to the idols, practising divination, from having cultfigures erected, from performing secret rites, and from defiling the cities by the carnage of gladiatorial combat."

(Cameron 1999: 161) 


\section{AD 325: Justinian's Code 11.44.1 ( $\approx$ Cod. Th. 15.12.1):}

Constantinus A. Maximo pp.

Cruenta spectacula in otio civili et domestica quiete non placent. Quaproper omnino gladiatores esse prohebemus.

PP. Beryto k. Oct. Paulino et Juliano conss.

(Potter, 2010: 597 and Frier et al. 2016: 2724)
Imperator Constantine Augustus to Maximus, Praetorian Prefect.

Bloody spectacles do not please us in civil ease and domestic quiet. For that reason, we altogether forbid the existence of gladiators.

Posted at Beirut on the Kalends of October (October 1) in the consulship of Paulinus and Julianus (325).

(Potter 2010: 597)

...Bloody spectacles in times of civil peace and domestic quiet are not pleasing, for which reason We prohibit gladiators from existing completely...

(Frier et al. 2016: 2725)

\section{AD 385: Theodosian Code 16.10.9=CJ.1.11.2:}

Idem aaa*. ad Cynegio praefecto praetorio.

$\mathrm{Ne}$ quis mortalium ita faciendi sacrificii sumat audaciam, ut inspectione iecoris extorumque praesagio vanae spem promissionis accipiat vel, quod est deterius, futura sub execrabili consultatione cognoscat. Acerbioris etenim inminebit supplicii cruciatus eis, qui contra vetitum praesentium vel futurarum rerum explorare temptaverint veritatem.

Dat. VIII kal. iun. Constantinopoli Arcadio a. I et Bautone v. c. conss. (385 mai. 25)

(https://droitromain.univ-grenoble-alpes. fr/\#10, manuscript: Staatsbibliothek $\mathrm{zu}$ Berlin, Ms. lat. 83)

*idem aaa. $=$ Gratian, Valentinian and Theodosius

\section{AD 391: Theodosian Code 16.10.1:}

Idem aaa.* ad Albinum praefectum praetorio.

Nemo se hostiis polluat, nemo insontem victimam caedat, nemo delubra adeat, templa perlustret et mortali opere formata simulacra suspiciat, ne divinis adque humanis sanctionibus reus fiat. Iudices quoque haec forma contineat, ut, si quis profano ritui deditus templum uspiam vel in itinere
The same Augustuses to Cynegrius, Praetorian Prefect.

No mortal shall assume the audacity of performing sacrifices, so that by the inspection of the liver and the presage of the entrails of the sacrificial victims, he may obtain the hope of a vain promise, or, what is worse, he may learn the future by an accursed consultation. The torture of a very bitter punishment shall threaten those persons who, in violation of Our prohibition, attempt to explore the truth of present or future events.

Given on the eight day before the Kalends of June at Constantinople in the year of the first consulship of Arcadius Augustus and the consulship of the most noble Bauto (May 25, 385).

(Pharr et al. 1952: 473)

The same Augustustes to Albinus, Praetorian Prefect.

No person shall pollute himself with sacrificial animals; no person shall slaughter an innocent victim; no person shall approach the shrines, shall wander through the temples, or revere to images formed by mortal labour, lest he become guilty by divine and human laws. Judges and gover- 
vel in urbe adoraturus intraverit, quindecim pondo auri ipse protinus inferre cogatur nec non officium eius parem summam simili maturitate dissolvat, si non et obstiterit iudici et confestim publica adtestatione rettulerit. Consulares senas, officia eorum simili modo, correctores et praesides quaternas, apparitiones illorum similem normam aequali sorte dissolvent.

Dat. VI kal. mart. Mediolano Tatiano et Symmacho conss. (391 febr. 24).

(after the Roman Law Library online: http://droitromain.upmf-grenoble.fr/ Constitutiones/CTh16.html\#10)

* idem aaa. = Gratian, Valentinian and Theodosius nors of provinces also shall be bound by the general rule that if any of them should be devoted to profane rules and should enter a temple for the purpose of worship anywhere, either on a journey or in the city, he shall immediately be compelled to pay fifteen pounds of gold, and his office staff shall pay a like sum with similar haste, unless they resist the judge and immediately report him by a public attestation. Governors with the rank of consular shall pay six pounds of gold each, their office staff a similar amount; those with the rank of corrector or praeses shall pay four pounds each, and their apparitors, by equal lot, a like amount.

Given on the sixth day before the Kalends of March at Milan in the year of the consulship of Tatianus and Symmachus. February 24, 391.

(Pharr et al. 1952: 473)

6. ca. AD 220s to 260s: Invitatio ad munera inscription from Stobi

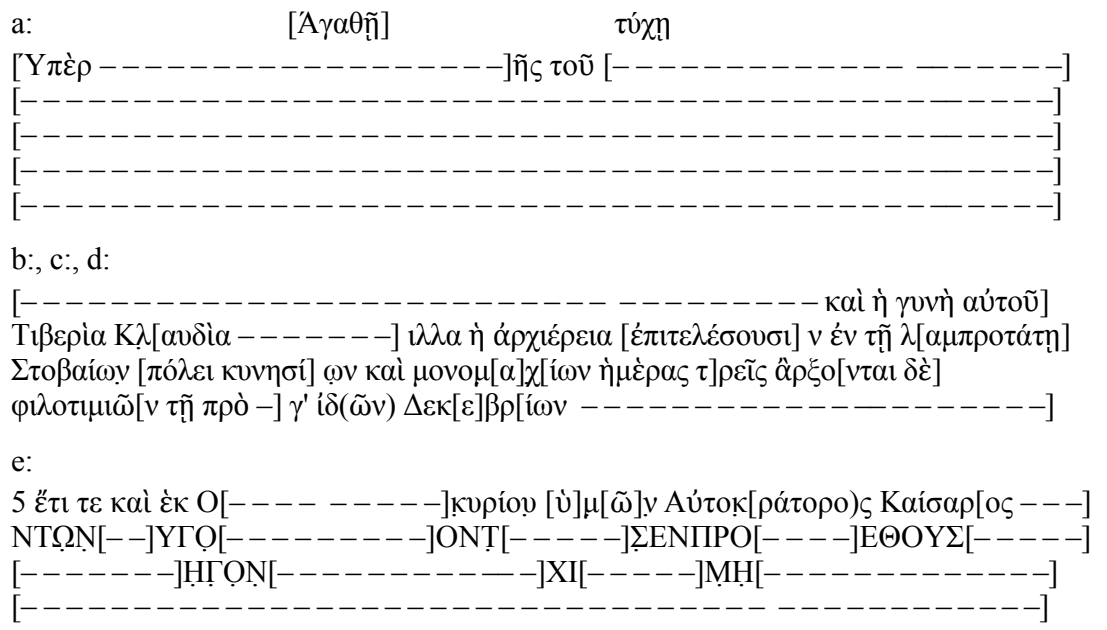

a: With good fortune. (For the health and safety and victory and eternal persistence of the greatest and most pious Emperor Caesar - - -

b-d: -------- (and his wife) Tiberia Claudia ----- , the high priestess, will sacrifice in the very glorious city of the Stobenses with beast hunts and gladiatorial fights for three days. The spectacles will start on the -3 day before the Ides of December - - - -

(Babamova 2018: 115 for original text and translation) 


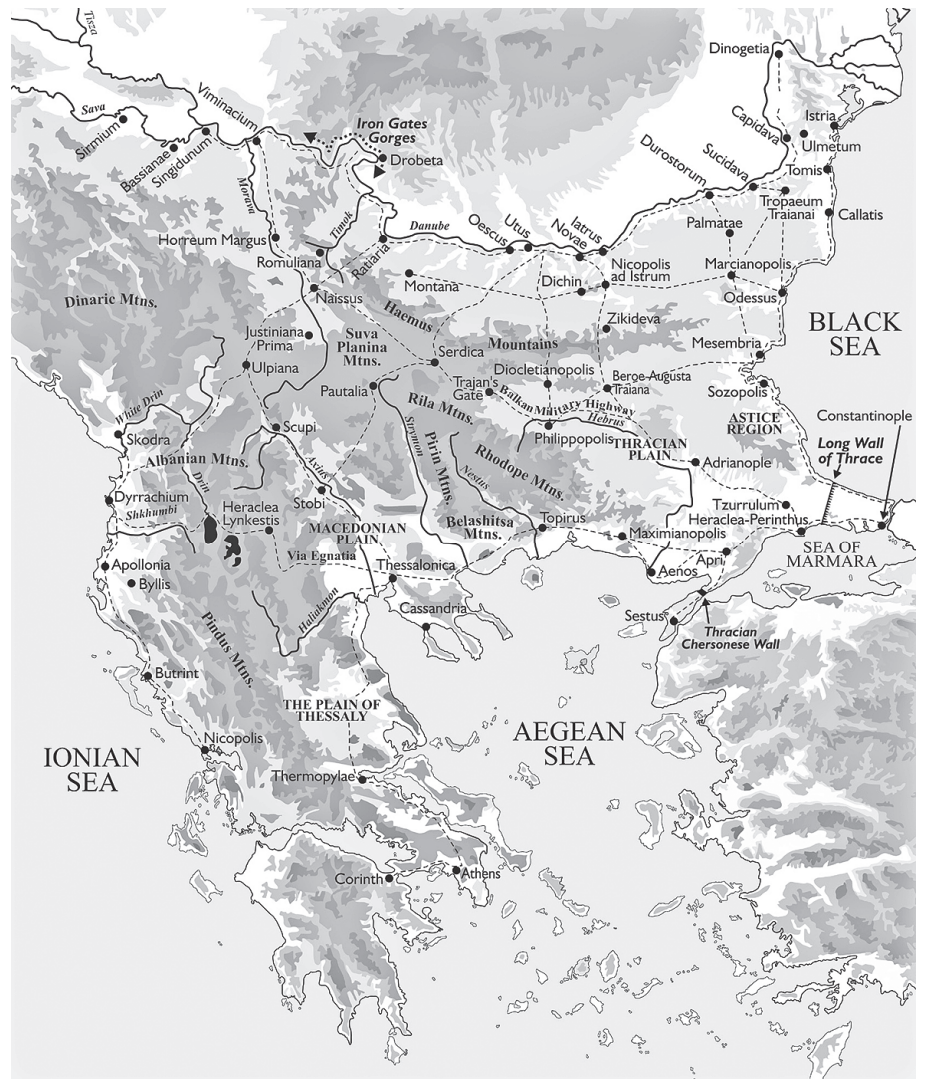

Figure 1. Geopolitical features of late antique Balkans (Sarantis 20129: 337)
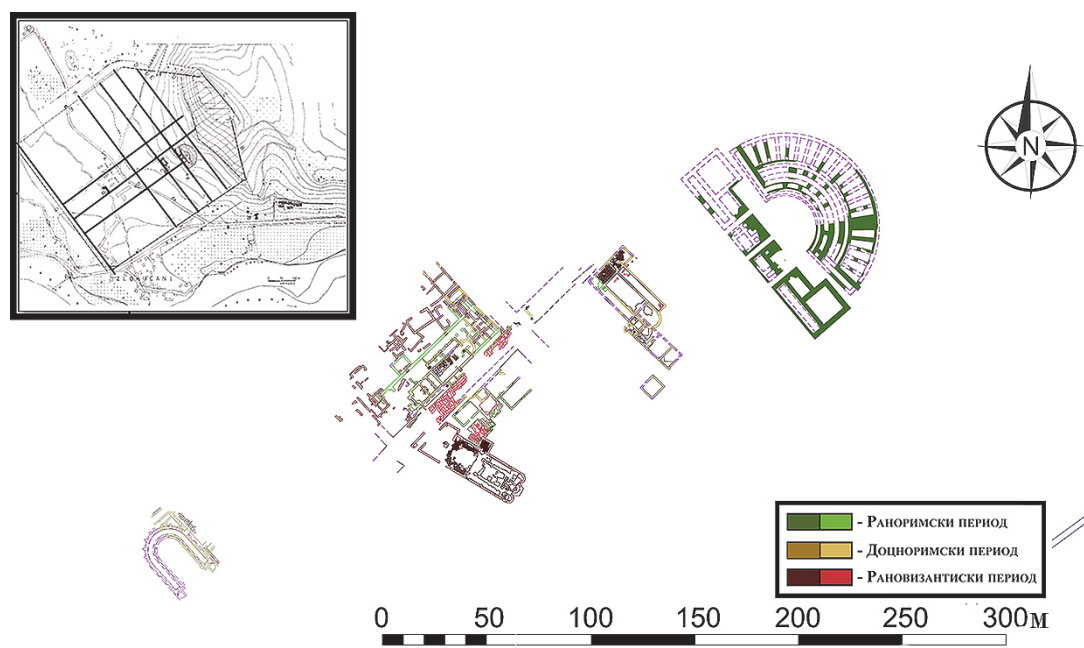

Figure 2. Plan of Scupi (Talevski 2018: 31) 


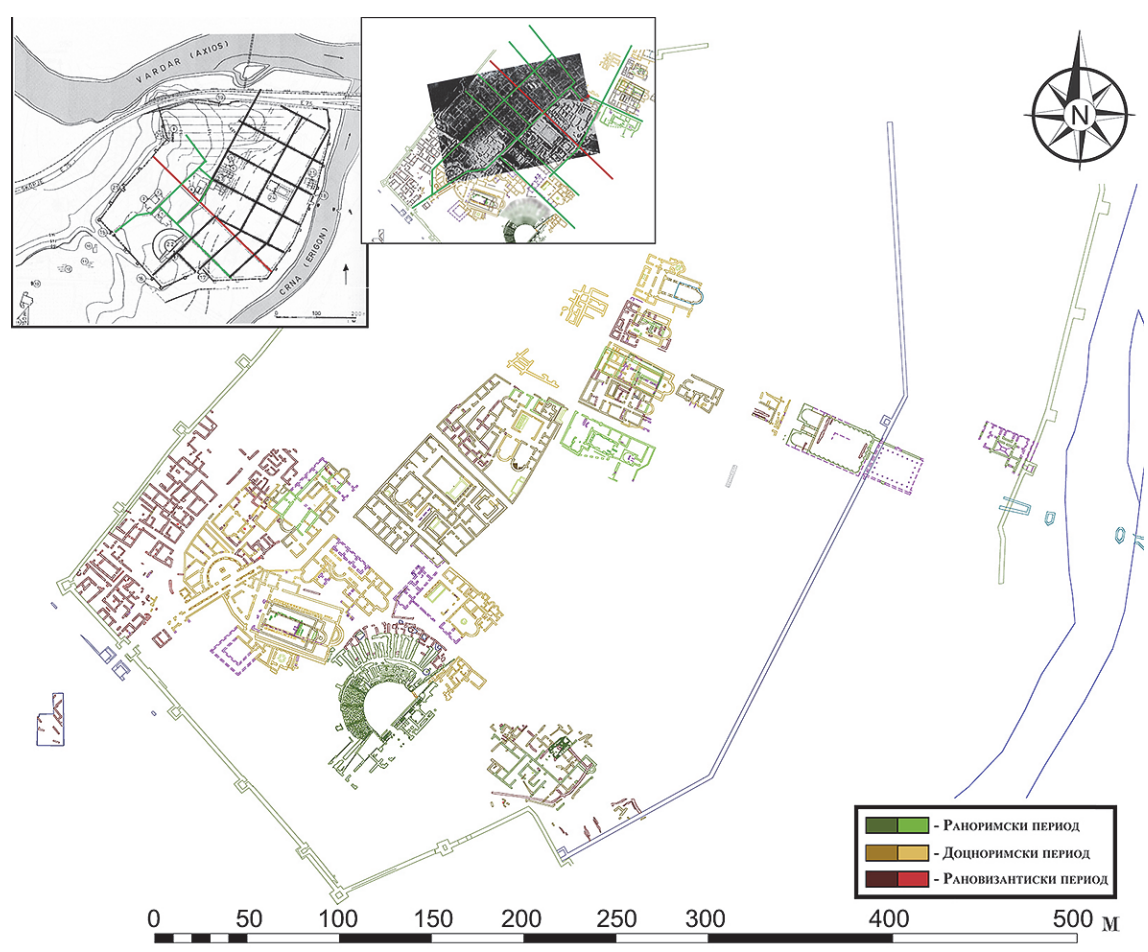

Figure 3. Plan of Stobi (Talevski 2018: 32)

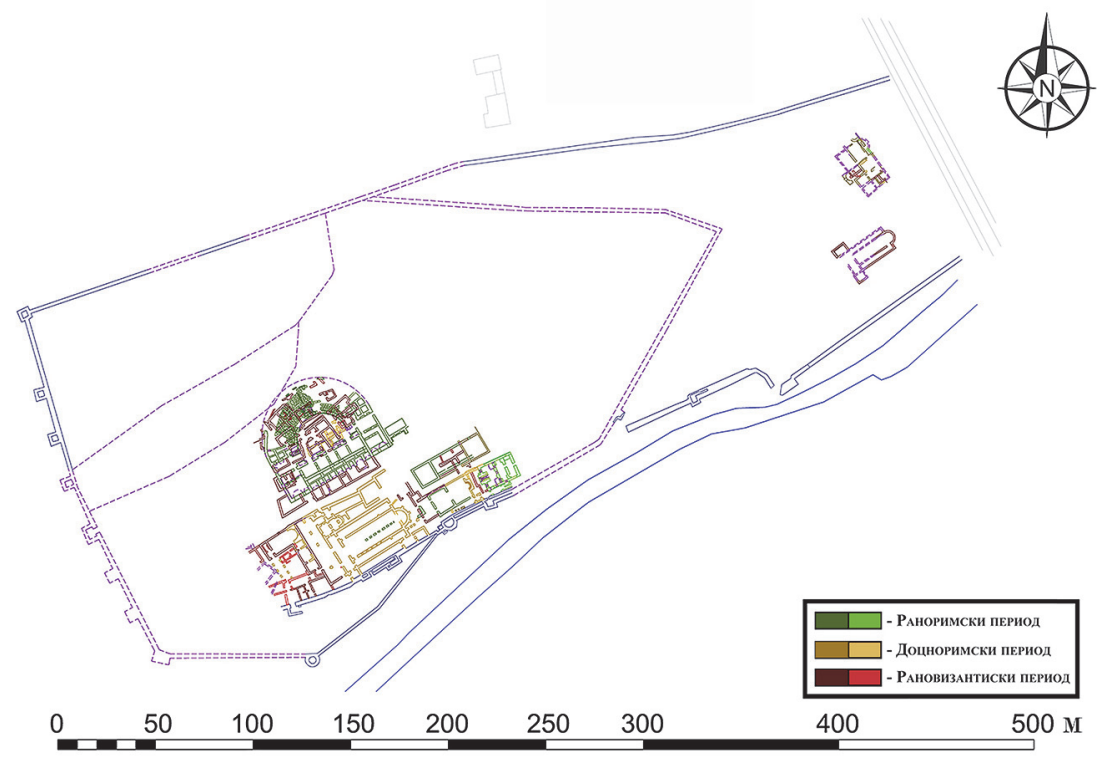

Figure 4. Plan of Heraclea Lyncestis (Talevski 2018: 33) 


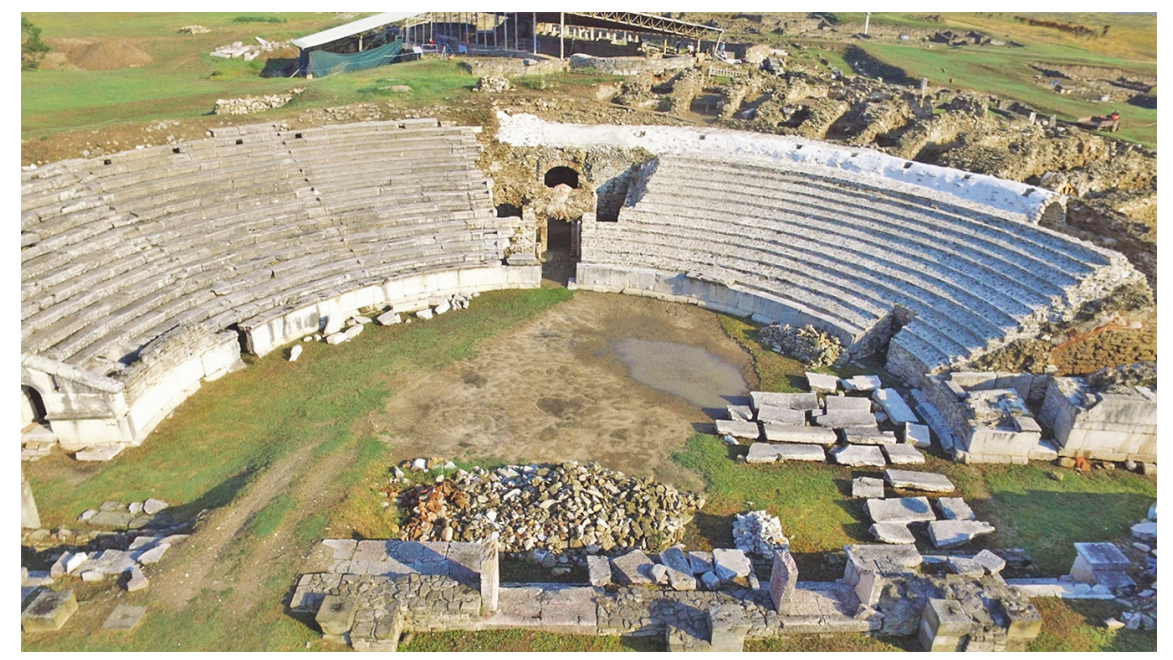

Figure 5. The Roman theatre at Stobi

(https://www.bhfieldschool.org/gallery/stobi-gallery, last consulted on July $22^{\text {nd }}, 2021$ )

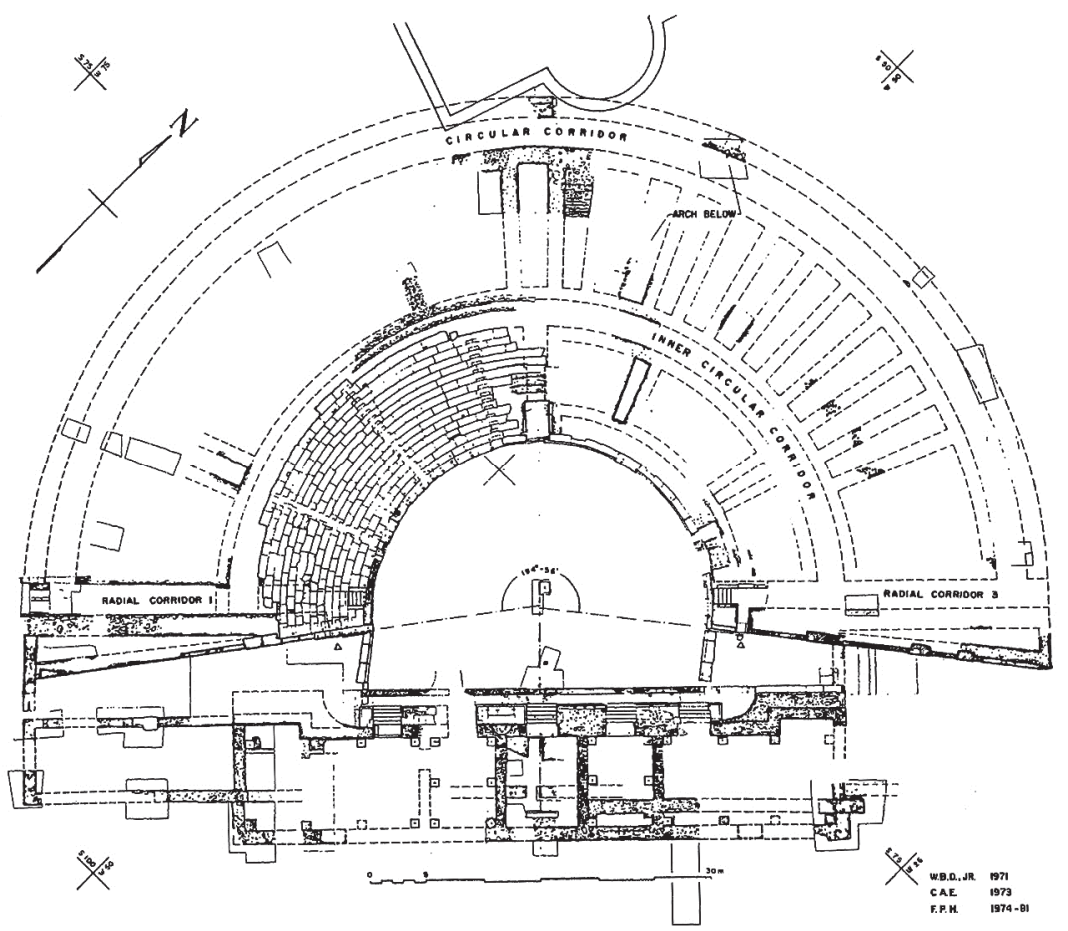

Figure 6. Plan of the Roman theatre at Stobi (Gebhard 1996: 58) 

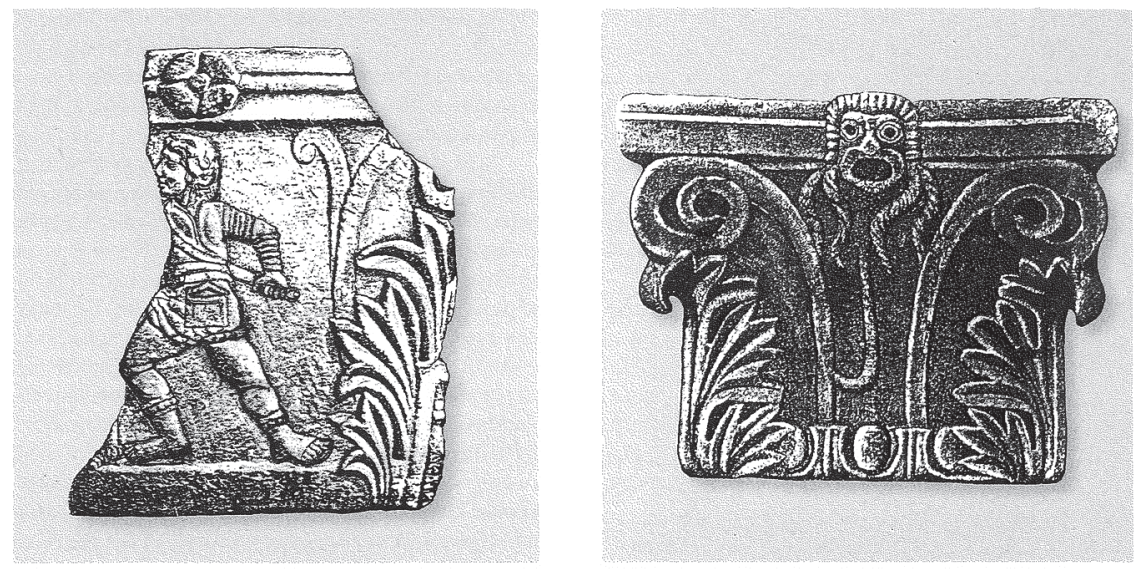

Figure 7. Pilaster-capitals from Stobi's theatre depicting a spectacle combatant and a theatrical mask (Mikulčić 2003: 73)

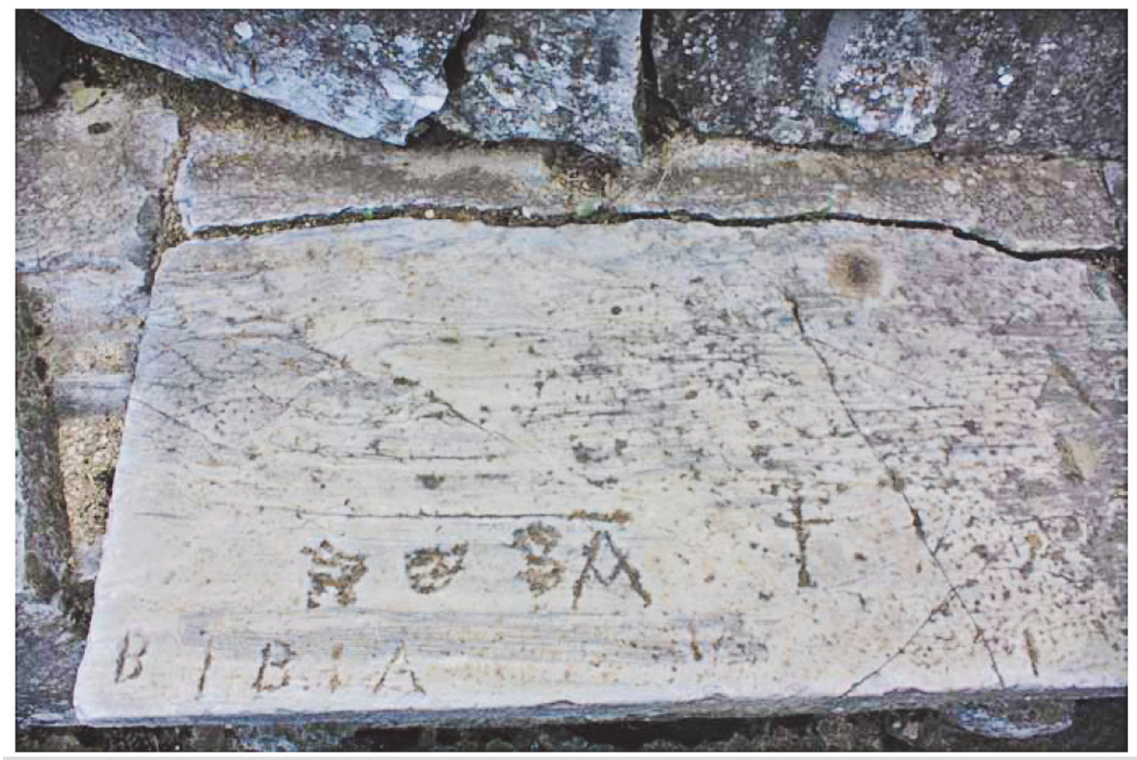

Figure 8. Inscribed name and a cross on a theatre seat from Stobi (Babamova 2018b: 270) 


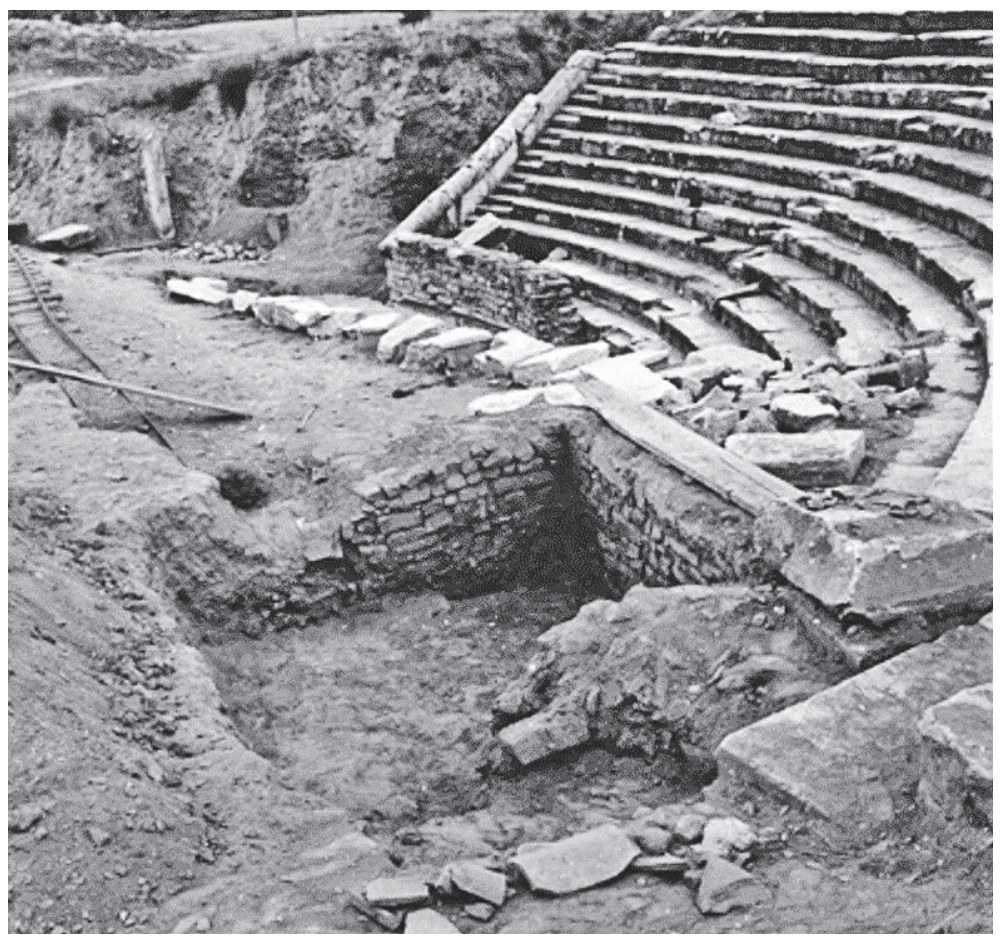

Figure 9. Late antique settlement atop the theatre at Stobi, mid- $20^{\text {th }} \mathrm{c}$. excavations (http://www.stobi.mk, last consulted on July $22^{\text {nd }}, 2021$ )

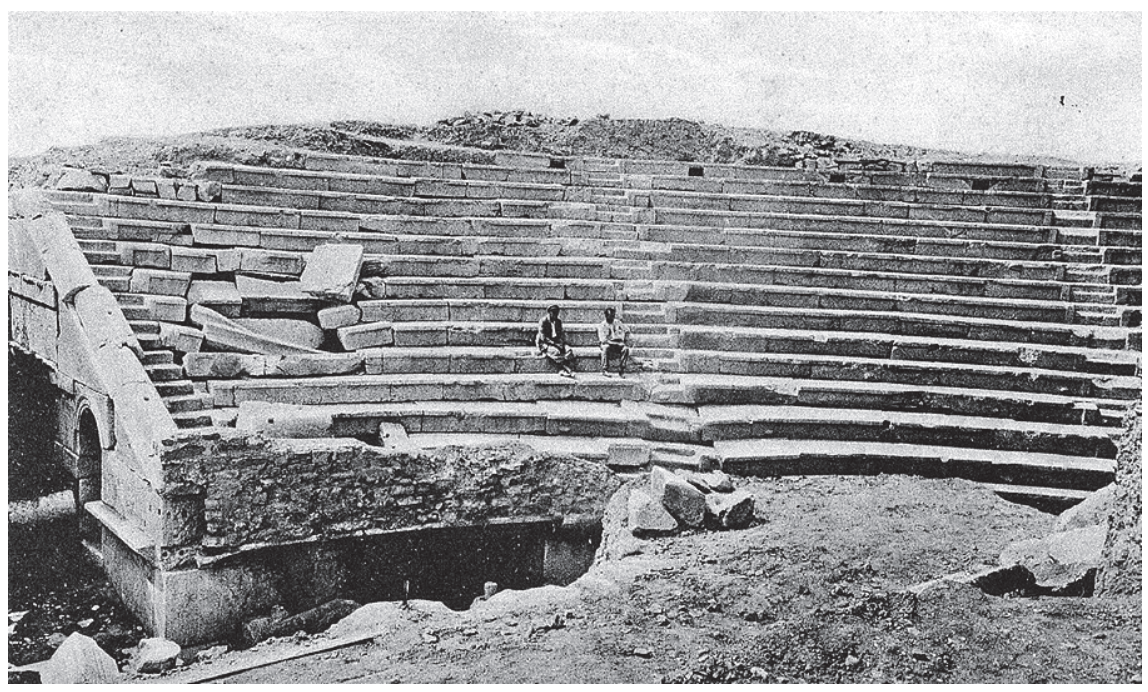

Figure 10. Permanent protective barrier added on to the theatre at Stobi (National Archives of North Macedonia, postcard from 1933) 


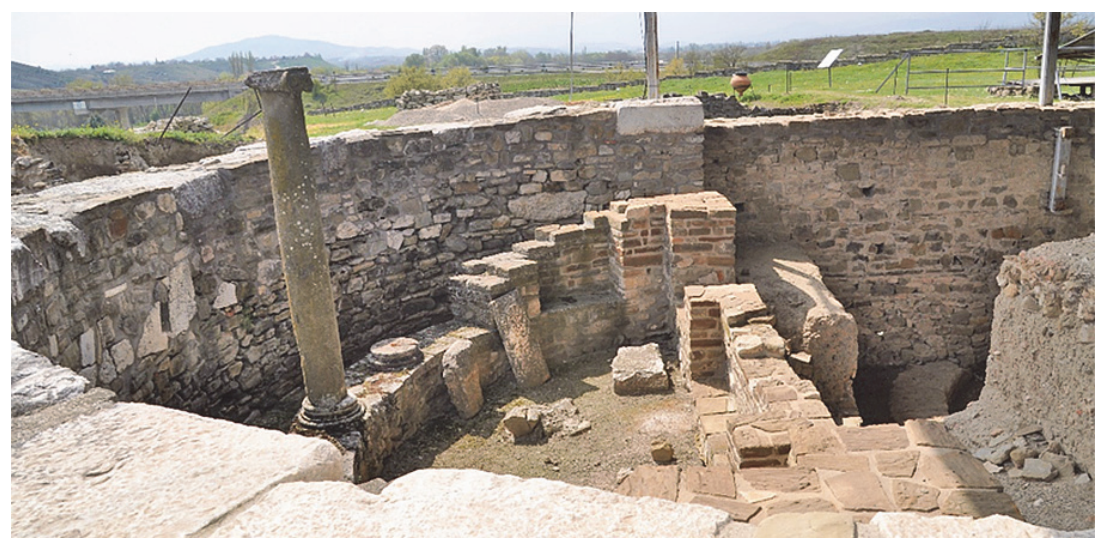

Figure 11. New Episcopal Basilica at Stobi: theatre seats reused in the apse, north view

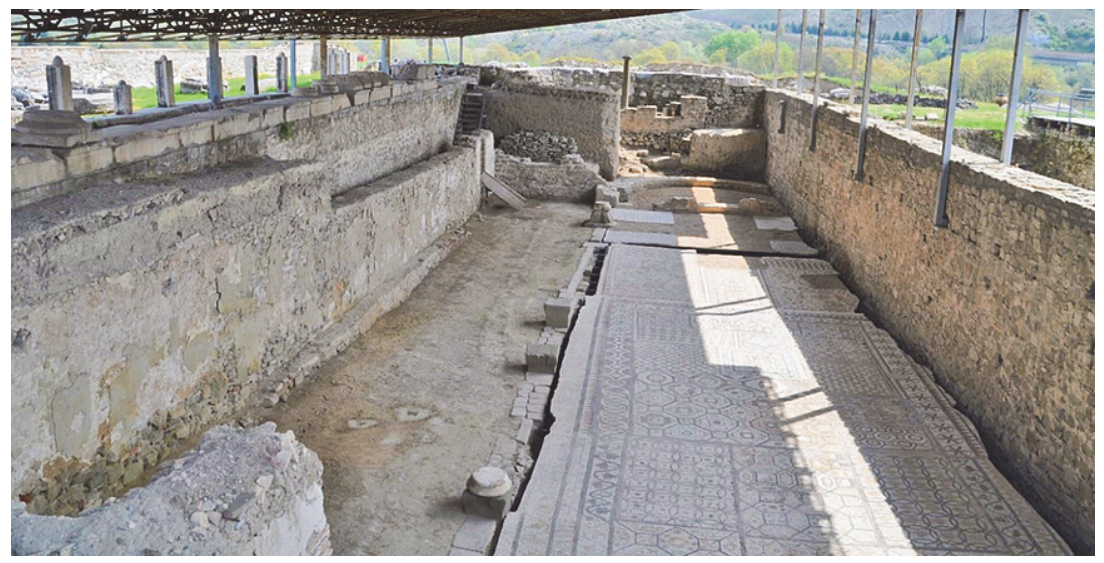

Figure 12. New Episcopal Basilica at Stobi: theatre seats reused in the naos, west view

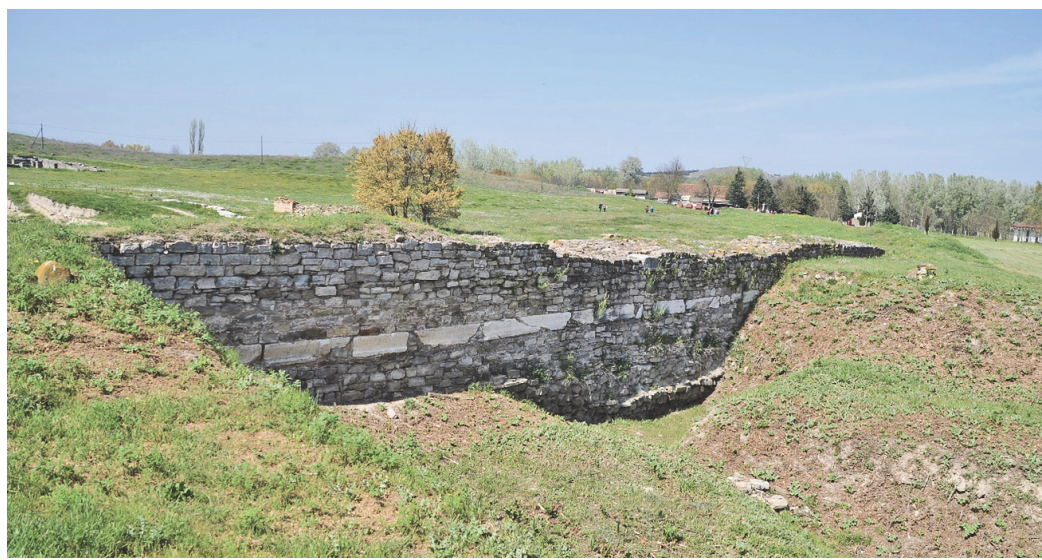

Figure 13. Theatre seats reused in Stobi's fortifications (both images by author, March 2016) 


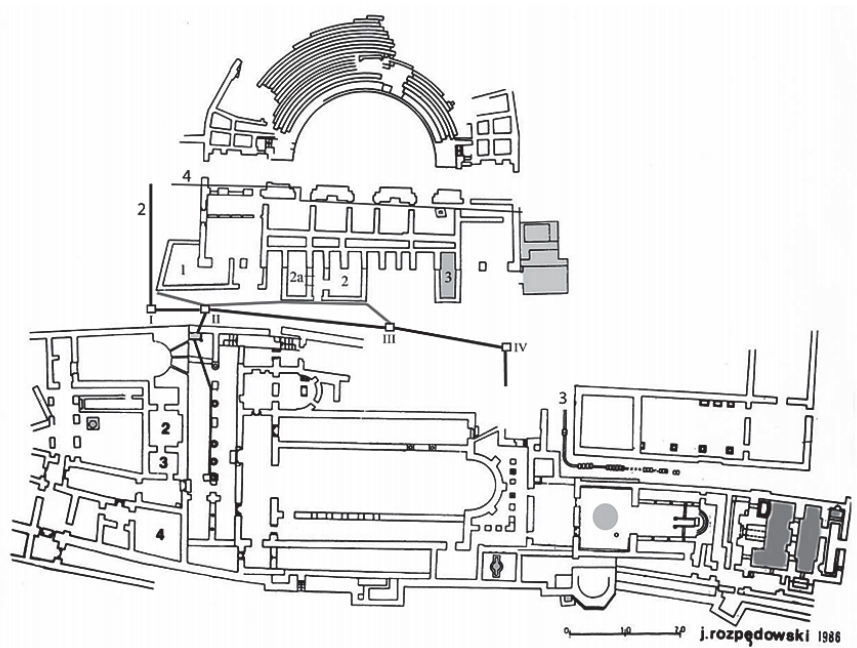

Figure 14. Plan of the urban core at Heraclea Lyncestis (Džidrova 2015: 291)

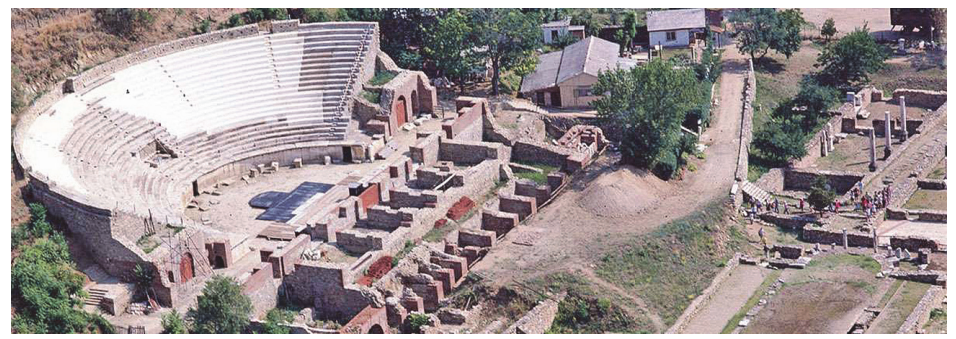

Figure 15. The theatre at Heraclea Lyncestis

(www.bhfieldschool.org/excursions/bitola-and-ancient-city-of-heraclea-lyncestis-macedonia)

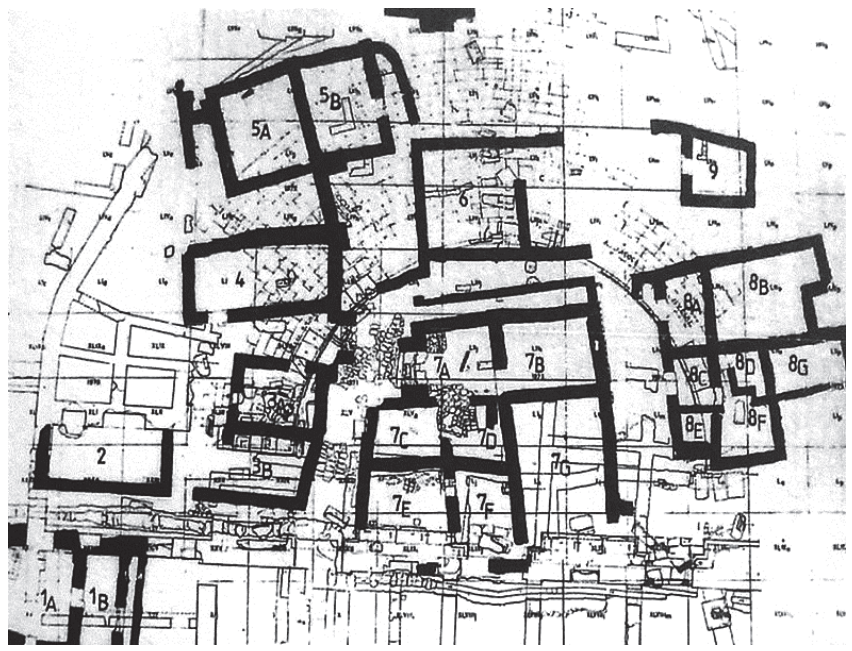

Figure 16. Late antique settlement atop Heraclea's theatre (Janakievski 1998: 165) 


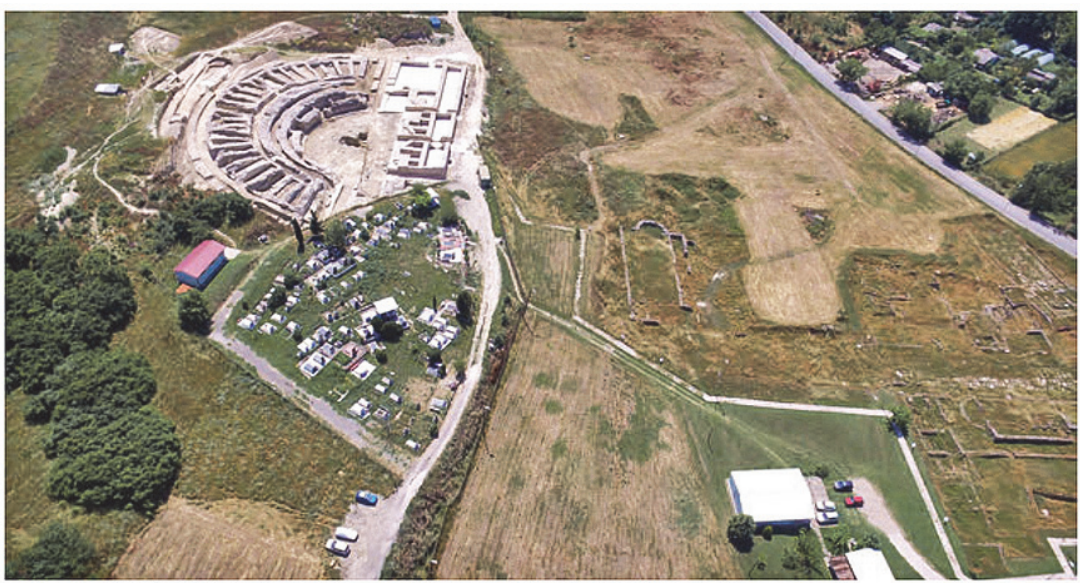

Figure 17. The Roman theatre at Scupi, 2016 excavations (Jakimovski et al. 2017: 31)

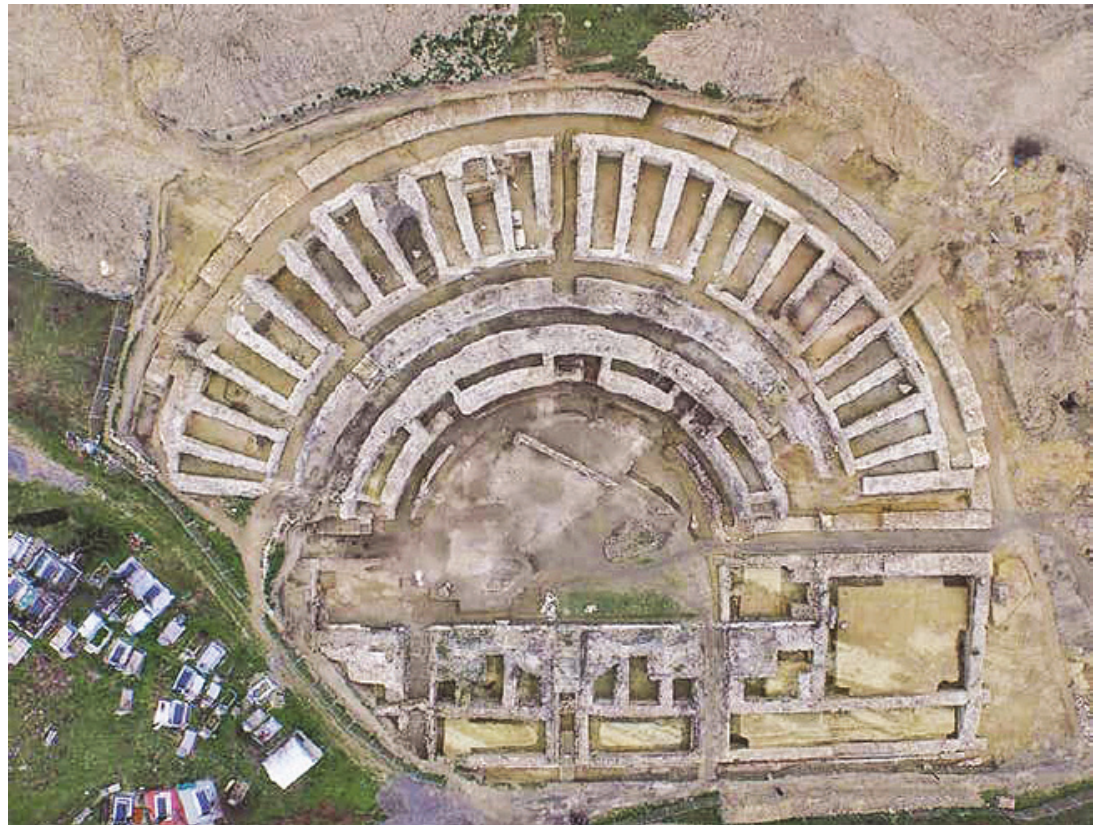

Figure18. Aerial view of the Roman theatre at Scupi (Jakimovski et al. 2017: 314) 

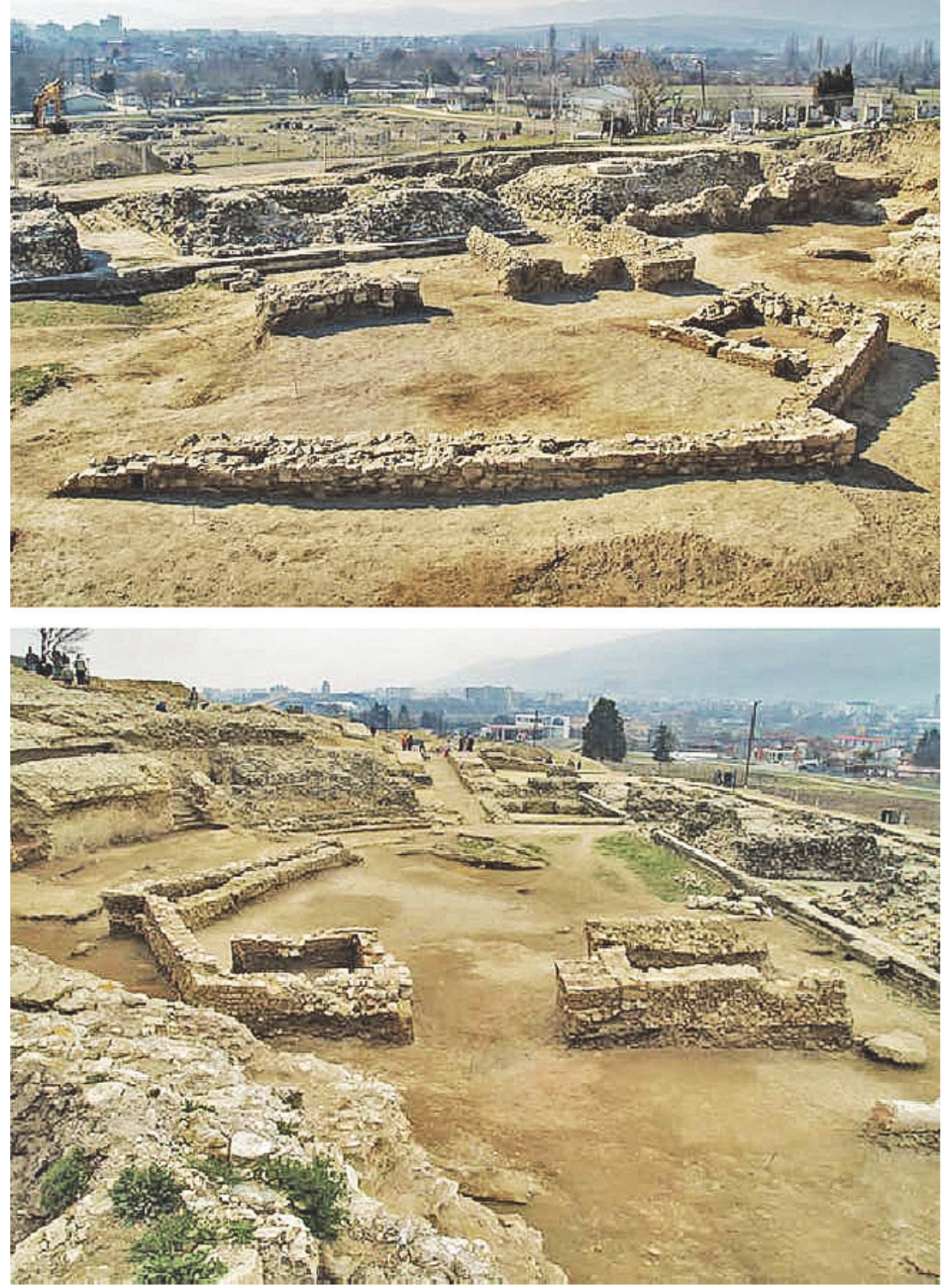

Figure 19. "Building 3" of the late antique settlement built within the abandoned theatre at Scupi (Ončevska-Todorovska 2017: 256 and 260) 


\section{MAJOR WORKS CITED}

\section{PRIMARY SOURCES:}

Ammianus Marcellinus, Chronicle $=$ Rolfe, J. C. Ammianus Marcellinus: with an English translation, vol. I-III. (Loeb Classics Library 300, 315, 331). Harvard University Press, 1971-72;

Code of Justinian = Frier, B. W. et al. The Codex of Justinian: a new annotated translation, with parallel Latin and Greek text. Cambridge University Press, 2016.

Eusebius of Caesarea, Life of Constantine $=$ Cameron, A. and Hall, S.G. Eusebius of Caesarea, Life of Constantine. (Clarendon Ancient Histories Series). Clarendon Press, 1999.

= Schaft, P. and Wace, H., editors Eusebius of Caesarea: Church History, Life of Constantine the Great, Oration of Constantine. (Nicene and Post-Nicene Fathers, Second series, vol. 1). T\&T Clark, 1981.

= Бешевлиев, В. и ости., уред. и прев. Гръики извори за бъїарскайа истиория, том 1 . (Извори за бъгарската историја 1). Бъгарска академия на науките, 1954. [= Beševliev, V. et al., editors and translators, Fontes graeci historiae bulgaricae, vol. 1. (Fontes historiae bulgaricae 1). Bulgarian academy of science, 1954.

Georgius Cedrenus, Concise History = Tartaglia, L., editor. Georgii Cedreni Histo- riarum compendium. (Supplemento al Bolletino dei classici 30). Bardi edizioni, 2016.

Hierocles, Synecdemus= Burckhardt, A., editor. Hieroclis Synecdemvs; accedvnt fragmenta apvd Constantinvm Porphyrogennetvm servata et nomina vrbivm mvtata. In aedibvs B. G. Tevbneri, 1893

John of Antioch, Fragmenta Historicum Graecorum = Mariev, S., editor. Ioannis Antiocheni fragmenta quae supersunt omnia. (Corpus Fontium Historiae Byzantinae, Series Berolinensis 47). De Gruyter, 2008.

John the Lydian, De mensibus= Bandy, A., Constentelons, D. J. and de Paulo, C. J. N., editors. The Works of Ioannis Lydus, I-IV: new critical translation of De Mensibus, De Ostentis and De Magistratibus. Edwin Mellen Press.

John Malalas, Chronicle=Jeffreys, E., et al., translators. The Chronicle of John Malalals: a translation. (Byzantina Australiensia 4). Australian Association for Byzantine Studies, 1986.

= Thurn, I., editor, Ioannis Malalae Chronographia . (Corpus Fontium Historiae Byzantinae, Series Berolinensis 35). Walter de Gruyter, 2000.

Joshua the Stylite, Chronicle $=$ Cave Wright, W. E., translator. The Chronicle of Joshua the Stylite composed in Syriac A.D. 507, with a translation into English and notes. Cambridge University Press, 1883.

Julian the Apostate, Misopogon= Cave Wright, W. E., translator. The works of Emperor Julian. (Loeb Classics Library 23). William Heinemann and Macmillian, 1913.

Marcellinus Comes, Chronicle $=$ Croke, B., editor and translator. Count Marcellinus and his chronicle. Oxford University Press, 2001;

Novels of Justinian = Miller, D. and Sarris, P., translators. The Novels of Justinian: a complete annotated English translation, I-II. Cambridge University Press, 2018.

Procopius, Secret History= Dewing, H. B., editor and translator. Procopius: Secret History, vol. VI. (LCL 290). Hutchinson and Harvard University Press, 1935..

Souda = Adler, A., editor. Suidae Lexicon. B. G. Teubner, 1928-1938.

Theodosian Code = Pharr, C. et al. The Theodosian Code and Novels and the Sirmodian Constitutions: A translation. Geoffrey Cumberlege and Oxford University Press, 1952.

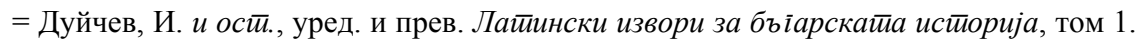
(Извори за бъгарската историја 2). Бъгарска академия на науките, 1958 [= Dujčev, I. et al., editors and translators. Fontes latini historiae bulgaricae, vol. 1. (Fontes historiae bulgaricae 2). Bulgarian academy of science, 1958. 


\section{SECONDARY SOURCES:}

Aleksova, B. and Wiseman, J., editors. Studies in the Antiquities of Stobi III. University of Texas in Austin, the Museum of Titov Veles and the Smithsonian Institution, 1981.

Ando, C. Narrating decline and fall, in Rousseau, P., and Raithel, J., editors, A Companion to late antiquity (Blackwell Companions to the ancient world). Blackwell, 2009.

Babamova, S. Notes on the prosopography from Stobi, in Blaževska, S. and Pavlovski, G., editors, Studies in the Antiquities of Stobi IV. National Institution and Museum Stobi, 2018a.

---. Stobi in late antiquity: epigraphic testimonia, in Breytenbach, C. and Ogereau, J. M., editors, Authority and Identity in Emerging Christianities in Asia Minor and Greece. (Ancient Judaism and Early Christianity 103). Brill, 2018b.

Biscardi, A. Una costituzione poco nota di Teodosio I, in Atti dell'Accademia Romanistica Costantiniana 4. Dipartimento Di Giurisprudenza e Università degli studi di Perugia, 1981.

Blaževska, S. and Radnjanski, J. The temple of Isis in Stobi, in Nikoloska, A. and Müskens, S. editors, Romanising the Oriental gods? Religious transformation in the Balkan provinces in the Roman period: new finds and perspectives. (Proceedings of the International Symposium Skopje, 18-21 September 2013). Leiden University and the Macedonian Academy of Arts and Sciences, 2015

Bomgardner, D. L. The story of the Roman Amphitheatre. Routledge, 2000.

Brandt, O. The archaeological record: problems of interpretation, in Rousseau, P. and Raithel J., editors, A Companion to late antiquity. (Blackwell Companions to the ancient world). Blackwell, 2009.

Brunnbauer, U. Serving the nation: historiography in the Republic of Macedonia (FYROM) after socialism. Historien 4 (2003-4), 161-82.

Busine, A. From stones to myth: temple destruction and civic identity in the late antique Roman East. Journal of Late Antiquity 6.2 (2013), 325-46.

DeVoe, R.F. The Christians and the games: the relationship between Christianity and the Roman games from the first through the fifth centuries A.D. (Doctoral dissertation). Texas Tech University, 1987.

Di Segni, L. The involvement of local, municipal and provincial authorities in the urban building in late antique Palestine and Arabia, in Humphrey, J. H., editor, The Roman and Byzantine Near East: some recent archaeological research. Journal of Roman Archaeology, 1995.

Donev, D., Gorgievski, D., Jacobs, I., Mladenović, D., Russell, B. and Strutt, K. Kostoperska Karpa: new results from an integrated intensive field and remote sensing survey. PATRIMONIUM.MK 15 (2017), 73-90.

Dunbabin, K. Athletes, acclamations, and imagery from the end of antiquity. Journal of Roman Archaeology 30 (2017), 151-74.

Dyggve, E. Le théatre mixte du Bas-empire d'après le théatre de Stobi et les diptyques consulaires première parte. Revue Archéologique 1 (1958), 137-57.

Egger. R. Градска црква у Стобима. Гласник Скойскої научної орушӣва 5 (1929a), 14-44 [=Egger, R. The urban basilica in Stobi. Journal of Skopje's scientific society 5 (1929a), 14-44].

Fargnoli, I.Sulla 'caduta senza rumore' delle Olimpiadi classiche. Revue Internationale des Droits de l'Antiquité 50 (2003), 119-54.

French, D. R. Christian emperors and pagan spectacles: the secularization of the ludi, A.D. 382-525 (Doctoral dissertation, University of California, 1985). Retrieved from_https://ezproxy-prd.bodleian.ox.ac.uk:2186/docview/303330881.

Gebhard, E. R. Protective devices in Roman theatres, in Mano-Zissi, Đ. and Wiseman, J., editors, Studies in the Antiquities of Stobi II. University of Texas in Austin, the Museum of Titov Veles and the Smithsonian Institution, 1975. 
---. The theater at Stobi: a summary, in Aleksova, B. and Wiseman, J., editors, Studies in the Antiquities of Stobi III. University of Texas in Austin, the Museum of Titov Veles and the Smithsonian Institution, 1981.

---. Discovery of the first theatre at Stobi. Folia Archaeologica Balkanica 2 (2011), 32546.

Greatrex, G. and Watt, J. W. One, two or three feasts? The Brytae, the Maiuma and the May festival at Edessa. Oriens Christanus 83 (1999), 1-20.

Gutsfeld, A. and Lehmann, S. Die Umgestaltung 'panhellenischer' Heiligtümer im spätantiken Griechenland: Das Beispiel Olympia, in Cancik, H. and Rüpke, J., editors, Römische Reichsreligion und Provinzialreligion: Globalisierungs- und Regionalisierungs-prozesse in der antiken Religionsgeschichte. Universität Erfurt, 2003.

Harries, J. Law and Empire in Late Antiquity. Cambridge University Press, 1999.

Hattersley-Smith, K. Byzantine public architecture between the fourth and early eleventh centuries AD, with special reference to the towns of Byzantine Macedonia. Society for Macedonian Studies, 1996.

Hoddinott, R.F. Early Byzantine churches in Macedonia and southern Serbia. A study of the origins and the initial development of East Christian art. Palgrave Macmillan, 1963.

Jacobs, I. Aesthetic maintenance of civic space: the 'Classical' City from the $4^{\text {th }}$ to the $7^{\text {th }}$ c. $A D$. (Orientalia Lovanniensia Analecta 193). Uitgeverij Peeters en Departement Oosterse Studies, 2013.

---. A time for prayer and a time for pleasure. Christianity's struggle with the secular world, in Engels, D. and van Nuffelen, P., editors, Religion and competition in the ancient world. (Collection Latomus 343). Éditions Latomus, 2014a.

---. Old habits die hard: a group of mythological statuettes from Sagalassos and the afterlife of sculpture in Asia Minor, in Kristensen, T. M. and Stirling, L., editors, The afterlife of Greek and Roman sculpture: late antique responses and practices. University of Michigan Press, 2016.

---. Cross graffiti as physical means to Christianize the classical city: an exploration of their function, meaning, topographical, and sociohistorical contexts, in Garipzanov, I. Goodson, C. and Maguire, H., editors, Graphic signs of identity, faith and power in late antiquity and the early Middle Ages. (Cursor Mundi 27). Brepols, 2017.

Jacobs, I. and Waelkens, M. 'Christians do not differ from other People:' the down-toearth religious stance of late antique Sagalassos (Pisidia), in Ameling, W., editor, Die Christianisierung Kleinasiens in der Spätantike (Asia Minor Studien 87). Dr. Rudolf Habelt GMBH, 2017.

Jacobs. I. and Stirling, L. Re-using the gods: a 6th-c. statuary display at Sagalassos and a re-evaluation of pagan mythological statuary in Early Byzantine civic space. Journal of Roman Archaeology, 30(2017), 196 - 226.

Jakimovski, A. Roman Theatre Scupi. Museum of City of Skopje, 2017.

Jakimovski, A., Jovanova, L., Ončevska-Todorovska, M., Jovanov, M. and Pavlovski, G. Roman Theatre-Scupi, in Jakimovski, A., editor, Roman Theatre Scupi. Museum of City of Skopje, 2017.

Jakimovski, A. and Šurbanovska, M. Forum Romanorum Stobis: Archaeological and tourist valuation of the Roman town of Stobi. CISS Macedonia, 2007.

Јанакиевски, Т. Доцноантичка микростанбена целина врз римскиот театар во Heraclea Lyncestis [=Janakievski, T. Late antique settlement built on top of the Roman theatre at Heraclea Lyncestis]. Macedoniae Acta Archaeologica 3(1977), 81-101.

---. Teaйар. Битола: Завод за заштита на спомениците на културата и музеј. [=Janakievski, T. Theatre. Cultural protection Centre and Museum, 1987.

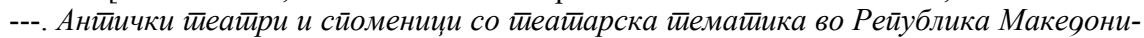
$j a$. Битола, Завод за заштита на спомениците на културата и Музеј Битола. [=Janakievski, T. Antique theatres and monuments with theatrical problematics from the Republic of Macedonia. Institute for protection of cultural heritage and Museum of Bitola, 1998. 
Jarić, J. Late Roman 'anti-pagan' laws and their appearance in the research of Roman theatres in R. Macedonia. 70 Years of Macedonian Historiography: Proceedings of the International Conference held in Skopje, $13^{\text {th }}$ and $14^{\text {th }}$ of December 2016 (2017), 387-416.

Jones, A. H. M. The Later Roman Empire 284-602: A Social Economic and Administrative Survey, Vols. I and II. Basil Blackwell, 1964.

Јованова, Л. и Ончевска-Тодоровска, М. Скуйи, секӣор Јуіоисӣочен беgем и комйлекс Терма-Базилика со айриум (истиражувања 2008-2013). Музеј на Град Скопје, 2017. [=Jovanova, L. and Ončevska-Todorovska, M. Skupi, Sector Southeastern fortification wall and the Thermae-Basilica with Atrium Complex. Museum of City of Skopje, 2017].

Kazhdan, A., editor. Oxford Dictionary of Byzantium. Oxford University Press, 1991.

Koltun-Fromm, N. Defining sacred boundaries: Jewish-Christian relations, in Rousseau, P. and Raithel, J., editors, A Companion to late antiquity. (Blackwell Companions to the ancient world). Blackwell, 2009.

Lee, A. D. The successors of Theodosius, in Cameron, A., Ward-Perkins, B. and Whitby, M. editors, Late Antiquity: Empire and Successors, AD 425-600. (The Cambridge Ancient History 14). University of Cambridge Press, 2008.

Lepelley, C. Le Cités de l'Afrique romaine au Bas-Empire, 2 vols. Etudes Augustiniennes, 1979-81.

Liebeschuetz, J. H. G. W. East and West in late antiquity: invasion, settlement, ethnogenesis and conflicts of religion. (Impact of Empire: Roman Empire, c. 200 B.CA.D.476, Vol. 20). Brill, 2016.

Lim, R. Consensus and Dissensus on Public Spectacles in Late Antiquity. Byzantinische Forschungen 21 (1994), 159-79.

---. Christianisation, secularization and the transformation of public life, in Rousseau, $\mathrm{Ph}$. and Raithel, J. editors, A Companion to late antiquity. (Blackwell Companions to the ancient world). Blackwell, 2009.

Ljubomirović, I. The epigraphic and archaeological work of Nikola Vulić in Macedonia. Annual of the Faculty of Philosophy in Priština 3 (2018), 249-257.

Loseby, S. T. (2009). Mediterranean cities, in Ph. and Raithel, J., editors, A Companion to late antiquity. (Blackwell Companions to the ancient world). Blackwell, 2009.

Makuljević, N. Art history in Serbia, Bosnia-Herzegovina and Macedonia, in Rampley, M. et al, editors, Art history and visual studies in Europe: transnational discourses and national frameworks. (Brill's studies in Intellectual History 4). Brill, 2012.

Malineau, V. Le théâtre dans l'Antiquité tardive de la Tétrarchie à Justinien: histoire des spectacles et des monuments (Doctoral dissertation). Paris, 2002.

Mano-Zissi, Đ. Antićki teatar u Stobima: antićki teatar na tlu Jugoslavije. Matica Srpska, 1981 [= Mano-Zissi, Đ. The ancient theatre at Stobi: ancient theatres in Yugoslavia. Matica Srpska, 1981].

Mano-Zissi, Đ. and Wiseman, J., editors Studies in the Antiquities of Stobi I and II. University of Texas in Austin, the Museum of Titov Veles and the Smithsonian Institution, 1973-1975.

Marmostein, A. The Synagogue of Claudius Tiberius Polycharmus in Stobi. The Jewish Quarterly Review, New Series 27.4 (1937), 373-84.

Микулчиќ, И. Анишички іраяови во Макеgонија. Македонска академија на науките и уметностите, 1999 [=Mikulčić, I. (1999). Ancient Cities in Macedonia. Macedonian Academy of Art and Sciences, 1999].

Mikulčić, I. Spätantike und frühbyzantinische Befestigungen in Nordmakedonien: Städte, Vici, Refugien, Kastelle. C.H. Beck, 2002.

Mikulčić, I. Stobi, an ancient city. Magor, 2003.

Mulryan, M. 'Paganism' in late antiquity: regional studies and material culture. In Lavan, L. and Mulryan, M, editors, The Archaeology of Late Antique 'Paganism.' Brill, 2011. 
Nikolovski, D. (2018). Commercial space at Stobi: The Semicircular Court. In S. Blaževska (Ed.), Studies in the Antiquities of Stobi IV (p. 308-41). Gradsko: National Institution and Museum Stobi.

Ončevska-Todorovska, M. Late antiquity settlement in the area of the Roman theatre in Scupi, in Jakimovski, A., editor, Roman Theatre Scupi. Museum of City of Skopje, 2017.

Ovadiah, A. Ancient Jewish communities in Macedonia, Thrace and Upper Epirus. Gerión 33 (2015), 211-27.

Pavlovski, G. The cavea of the theatre at Stobi. Results from the excavations in 2009, 2010 and 2012, in Blaževska, S. editor, Studies in the Antiquities of Stobi IV. National Institution and Museum Stobi, 2018.

Potter, D. Constantine and the gladiators. Classical Quarterly 60.2 (2010), 596-609. .

Puk, A. Das Römische Speielewesen in Der Späteantike. (Miilenium-Studien zu Kultur und Geschichte des ersten Jahrtausends n. Chr., Band 48). De Gruyter, 2014.

Remijsen, S. The end of Greek athletics in late antiquity. (Greek Culture in the Roman World). Cambridge University Press, 2015.

Saradi, H. The Byzantine city in the sixth century: literary images and historical reality. Society of Messenian Archaeological Studies, 2006.

Saradi, H. and Eliopoulos, D. Late paganism and Christianisation in Greece, in Lavan, L. and Mulryan, M., editors, The Archaeology of late antique 'paganism.' (Late Antique Archaeology 7). Brill, 2011.

Sarantis, A. Military provisioning in the sixth-century Balkans. Journal of Late Antiquity 12.2 (2019), 329-79.

Saria, B. Pozorište u Stobima. Godišnjak Muzeja Juzne Srbije 1 (1937) 1-68 [= Saria, B. The Theatre at Stobi. Annual of the Museum of South Serbia 1 (1937) 1-68].

Sear, F. Roman theatres: an architectural study. Oxford University Press, 2006.

Segal, A. Theatres in Roman Palestine and Provincia Arabia. Brill, (1995).

Snively, C. Macedonia in late antiquity, in Roisman, J. and Worthington, B., editors, $A$ Companion to Ancient Macedonia. Willey-Blackwell, 2010.

Stirling, L. and Kristensen, T. M., editors. The afterlife of Greek and Roman sculpture: late antique responses and practices. University of Michigan Press, 2016.

Talevski, H. Early Roman heritage and potential influence on the residential and sacral architecture within the Late Roman urban settlements on the territory of the Republic of Macedonia. Balcanoslavica 47.1 (2018), 25-43.

Teja, A. L'édit de Théodose et la fin des Jeux Olympiques, in Renson, R. and Lämmer, M., editors, The Olympic Games through the ages: Greek antiquity and its impact on modern sport. Proceedings of the 13th International HISPA Congress (Olympia, May 22-28, 1989). Hellenic Sport Research, 1991.

Treadgold, W. The Early Byzantine historians. Palgrave Macmillan, 2007.

Vesevska, I. T. Ascending from blood: Early Christian architecture, ancient theatre and the cult of the martyrs. Folia Archaeologica Balcanica 4 (2018), 363-76.

Webb, R. Demons and dancers. Performance in late antiquity. Harvard University Press, 2008.

Weiler, I. Der 'Niedergang' und dase Ende der antiken Olympischen Spiele in der Forschung. Grazer Beiträge 12.3 (1985-6), 235-63.

Weir, R. Roman Delphi and its Pythian Games. John and Erica Hedges Ltd, 2004.

Weiss, Z. Public spectacles in Roman and late antique Palestine. Harvard University Press, 2014.

Wiseman, J. The city in Macedonia Secunda, in Villes et peuplement dans l'Illyricum protobyzantin. Actes du colloque de Rome (12-14 mai 1982) (p. 289-314). (Collection de l'École française de Rome 77). École Française de Rome, 1984. 